\title{
Inflammation-Induced Adverse Pregnancy and Neonatal Outcomes Can Be Improved by the Immunomodulatory Peptide Exendin-4
}

\author{
Valeria Garcia-Flores ${ }^{1,2,3,4}$, Roberto Romero ${ }^{1,2,5,6,7}$, Derek Miller ${ }^{1,2,3,8}, Y_{i} X_{u^{1,2,3}}$, \\ Bogdan Done ${ }^{1,2,3}$, Chharitha Veerapaneni ${ }^{3}$, Yaozhu Leng ${ }^{1,2,3}$, Marcia Arenas-Hernandez ${ }^{1,2,3,9}$, \\ Nabila Khan ${ }^{3}$, Bogdan Panaitescu ${ }^{1,2,3}$, Sonia S. Hassan ${ }^{1,2,3}$, Luis Marat Alvarez-Salas ${ }^{4}$ \\ and Nardhy Gomez-Lopez $1,2,3,8 *$
}

${ }^{1}$ Perinatology Research Branch, Program for Perinatal Research and Obstetrics, Division of Intramural Research, Eunice Kennedy Shriver National Institute of Child Health and Human Development, NICHD/NIH/DHHS, Detroit, MI, United States, ${ }^{2}$ Perinatology Research Branch, Program for Perinatal Research and Obstetrics, Division of Intramural Research, Eunice Kennedy Shriver National Institute of Child Health and Human Development, NICHD/NIH/DHHS, Bethesda, MD, United States, ${ }^{3}$ Department of Obstetrics and Gynecology, Wayne State University School of Medicine, Detroit, MI, United States, ${ }^{4}$ Departamento de Genética y Biología Molecular, Cinvestav, Mexico City, Mexico, ${ }^{5}$ Department of Obstetrics and Gynecology, University of Michigan, Ann Arbor, MI, United States, ${ }^{6}$ Department of Epidemiology and Biostatistics, Michigan State University, East Lansing, MI, United States, ${ }^{7}$ Center for Molecular Medicine and Genetics, Wayne State University, Detroit, MI, United States, ${ }^{8}$ Department of Immunology, Microbiology and Biochemistry, Wayne State University School of Medicine, Detroit, MI, United States, ${ }^{9}$ Departamento de Biomedicina Molecular, Cinvestav, Mexico City, Mexico

Reviewed by: Dong Li,

Jilin University, China Xuanjun Wang, Yunnan Agricultural University, China

*Correspondence:

Nardhy Gomez-Lopez nardhy.gomez-lopez@wayne.edu, ngomezlo@med.wayne.edu

Specialty section: This article was submitted to Inflammation,

a section of the journal

Frontiers in Immunology

Received: 15 November 2017 Accepted: 23 May 2018

Published: 18 June 2018

Citation:

Garcia-Flores V, Romero R, Miller D, $X u Y$, Done B, Veerapaneni C, Leng Y, Arenas-Hernandez M, Khan N,

Panaitescu B, Hassan SS, Alvarez-Salas $L M$ and GomezLopez N (2018) InflammationInduced Adverse Pregnancy and Neonatal Outcomes Can

Be Improved by the Immunomodulatory Peptide Exendin-4.

Front. Immunol. 9:1291. doi: 10.3389/fimmu.2018.01291
Preterm birth is the leading cause of neonatal morbidity and mortality worldwide. Inflammation is causally linked to preterm birth; therefore, finding an intervention that dampens maternal and fetal inflammatory responses may provide a new strategy to prevent adverse pregnancy and neonatal outcomes. Using animal models of systemic maternal inflammation [intraperitoneal injection of lipopolysaccharide (LPS)] and fetal inflammation (intra-amniotic administration of LPS), we found that (1) systemic inflammation induced adverse pregnancy and neonatal outcomes by causing a severe maternal cytokine storm and a mild fetal cytokine response; (2) fetal inflammation induced adverse pregnancy and neonatal outcomes by causing a mild maternal cytokine response and a severe fetal cytokine storm; (3) exendin-4 (Ex4) treatment of dams with systemic inflammation or fetal inflammation improved adverse pregnancy outcomes by modestly reducing the rate of preterm birth; (4) Ex4 treatment of dams with systemic, but not local, inflammation considerably improved neonatal outcomes, and such neonates continued to thrive; (5) systemic inflammation facilitated the diffusion of Ex4 through the uterus and the maternal-fetal interface; (6) neonates born to Ex4-treated dams with systemic inflammation displayed a similar cytokine profile to healthy control neonates; and (7) treatment with Ex4 had immunomodulatory effects by inducing an M2 macrophage polarization and increasing anti-inflammatory neutrophils, as well as suppressing the expansion of CD8+ regulatory $T$ cells, in neonates born to dams with systemic inflammation. Collectively, these results provide evidence that dampening maternal systemic inflammation through novel interventions, such as Ex4, can improve the quality of life for neonates born to women with this clinical condition.

Keywords: amniotic fluid, clinical chorioamnionitis, fetal inflammatory response syndrome, intra-amniotic infection/inflammation, M2 macrophages, neutrophils, regulatory T cells, preterm labor and birth 


\section{INTRODUCTION}

Preterm birth is one of the most common, yet harmful, obstetrical syndromes (1) and is the leading cause of perinatal morbidity and mortality worldwide (2-4). Up to $70 \%$ of all preterm birth are preceded by spontaneous preterm labor $(5,6)$, a syndrome comprised of multiple pathological processes (1). While many putative causes are associated with spontaneous preterm labor, the only one that is causally linked to preterm birth is inflammation/ infection $(7,8)$. Inflammation can be due to microorganisms (i.e., intra-amniotic infection) or danger signals derived from necrosis and cellular stress (i.e., sterile intra-amniotic inflammation) (9-14). Systemically, intra-amniotic infection can be manifested as clinical chorioamnionitis, which refers to the presence of maternal fever associated with clinical signs (foul-smelling discharge and uterine tenderness as well as maternal and fetal tachycardia) and laboratory abnormalities such as leukocytosis (15-18). Locally, intra-amniotic infection is characterized by an increased white blood cell count (19-22) and elevated concentrations of cytokines (23) and lipid mediators (e.g., prostaglandins) (24-31) in the amniotic cavity. This local inflammatory response can indicate a systemic activation of the fetal innate immune system, a phenomenon referred to as fetal inflammatory response syndrome (FIRS) (32, 33). Clinically, FIRS is defined by elevated cytokines in the fetal plasma, such as IL-6 (34), and by the presence of the fetus-related histopathological lesions funisitis and chorionic vasculitis (35-37). Fetuses with FIRS are often born to mothers with subclinical microbial invasion of the amniotic cavity (32). If the infection reaches the fetus, it may result in a systemic fetal infection that can progress toward multiple organ dysfunction, septic shock, and death (38). Finding a treatment for the prevention of inflammation-induced adverse pregnancy outcomes (39, 40 ), which can target both the maternal and fetal inflammatory responses, is critical.

Several substances with anti-inflammatory properties have been suggested as possible candidates for the prevention of inflammation-induced adverse pregnancy outcomes (41). In vivo studies using pregnant mice have shown that antibodies against cytokines (42) or their receptors (43), cytokine antagonists (44, $45)$, cytokine-suppressive anti-inflammatory drugs (46), COX-2 inhibitors $(47)$, hormones such as progesterone $(48,49)$ and human chorionic gonadotropin (50), resveratrol (51), resolvins (52), PPAR $\gamma$ agonists (53-56), statins (57), and probiotics (58) are potential anti-inflammatory therapies for preterm birth prevention. Yet, further investigation is still required to determine the efficacy and safety of such treatments (41). Herein, we propose the use of a peptide, exendin-4 (Ex4), as an alternative approach for preventing inflammation-induced preterm labor and birth and adverse neonatal outcomes. In general, peptides are selective and efficacious signaling molecules that bind to a specific cell-surface receptor, which triggers intracellular effects (59). Because of their attractive pharmacological profile and intrinsic properties as well as their specificity, peptides represent an excellent alternative for the design of novel therapeutic approaches with potential safety, tolerability, and efficacy in humans (59).

Exendin-4 is a glucagon-like peptide-1 receptor (GLP1R) agonist, which is commonly used to treat diabetes mellitus type 2 (60).
GLP1R is expressed in pancreatic beta cells and activation of this receptor stimulates the adenylyl cyclase pathway, which results in increased synthesis and release of insulin (61). In addition to the pancreas, GLP1R is expressed in several other organs including the intestine, lung, kidney, breast, and brain (62). The widespread distribution of this receptor in organs has resulted in multiple studies examining this receptor as a target for the treatment of various diseases. For example, Ex4 reduces liver damage (63) as well as inflammation and atherosclerosis (64). This peptide also has protective effects in renal injury (65) and post-myocardial infarction (66) by reducing inflammation. Moreover, Ex4 has potent immunomodulatory effects in both mice and humans as evidenced by the following demonstrations: Ex4 (a) prevents inflammation-induced migration of macrophages and their release of pro-inflammatory cytokines in vitro (67) and in vivo (64); (b) improves neutropenia and decreases the systemic levels of pro-inflammatory cytokines in a rat model of endotoxemia (68); (c) reduces the expression of iNOS and the production of reactive oxygen species, as well as the release of pro-inflammatory cytokines by in vitro M1-polarized human macrophages $(69,70)$; (d) attenuates the release of pro-inflammatory cytokines (e.g., TNF $\alpha$, IL-1 $\beta$, and IL-6) and chemokines (e.g., CCL5/RANTES and CXCL10/IP-10) by peripheral blood mononuclear cells from type 2 diabetic patients, which is likely mediated by the suppression of the p38 MAPK pathway (71); and (e) suppresses subcutaneous tumor growth in a dose-dependent manner by increasing Th1 pro-inflammatory responses (e.g., IFN $\gamma$ and IL-1) and reducing CD4+ Foxp3+ regulatory T cells (Tregs) (72). Therefore, we propose that Ex4 could prevent adverse pregnancy and neonatal outcomes by exhibiting immunomodulatory effects and dampening maternal and fetal inflammation.

The aims of this study were (1) to evaluate the maternal and fetal cytokine responses in systemic and local models of inflammation-induced preterm birth and adverse neonatal outcomes; (2) to determine whether an anti-inflammatory peptide, Ex4, can dampen the inflammation to prevent adverse pregnancy and neonatal outcomes; (3) to localize Ex4 in the maternal and fetal tissues; and (4) to investigate the anti-inflammatory properties of Ex4 on the neonatal immune response by measuring the plasma cytokine response, inflammation-related gene expression, M1-M2 macrophage polarization, pro- and anti-inflammatory neutrophil phenotypes, and CD4+ and CD8+ Treg subsets.

\section{MATERIALS AND METHODS}

\section{Animals}

C57BL/6 (B6) mice were purchased from The Jackson Laboratory in Bar Harbor, ME, USA, and bred in the animal care facility at the C.S. Mott Center for Human Growth and Development at Wayne State University, Detroit, MI, USA. All mice were housed under a circadian cycle ( $12 \mathrm{~h}$ light/12 h dark). Females 8-12 weeks old were mated with males of the same background and proven fertility. Female mice were checked daily between 8:00 a.m. and 9:00 a.m. for the appearance of a vaginal plug, which indicated 0.5 days post coitum (dpc). Females were then placed into new cages, and their weights were monitored daily. A gain of two or more grams 
by $12.5 \mathrm{dpc}$ confirmed pregnancy. All procedures were approved by the Institutional Animal Care and Use Committee at Wayne State University (Protocol No. A-07-03-15).

\section{Animal Models of Preterm Birth/Fetal Inflammatory Response}

Intra-amniotic administration of lipopolysaccharide (LPS) (73): pregnant $\mathrm{B} 6$ mice were anesthetized on $16.5 \mathrm{dpc}$ by inhalation of $2-3 \%$ isoflurane (Aerrane, Baxter Healthcare Corporation, Deerfield, IL, USA) and 1-2 L/min of oxygen in an induction chamber. Anesthesia was maintained with a mixture of $1.5-2 \%$ isoflurane and $1.5-2 \mathrm{~L} / \mathrm{min}$ of oxygen. Mice were positioned on a heating pad and stabilized with adhesive tape. Fur removal from the abdomen and thorax was achieved by applying Nair cream (Church \& Dwight Co., Inc., Ewing, NJ, USA) to those areas. Body temperature was maintained in the range of $37 \pm 1^{\circ} \mathrm{C}$ and detected with a rectal probe (VisualSonics, Toronto, ON, Canada), and respiratory and heart rates were monitored by electrodes embedded in the heating pad. An ultrasound probe was fixed and mobilized with a mechanical holder, and the transducer was slowly moved toward the abdomen. Ultrasound-guided intra-amniotic injection of LPS (Escherichia coli O111:B4; SigmaAldrich, St. Louis, MO, USA) at a concentration of $100 \mathrm{ng}(n=8)$ dissolved in $25 \mu \mathrm{L}$ of sterile $1 \times$ phosphate-buffered saline (PBS; Fisher Scientific Bioreagents, Fair Lawn, NJ, USA) was performed in each amniotic sac using a 30-G needle (BD PrecisionGlide Needle, Becton Dickinson, Franklin Lakes, NJ, USA). Controls were injected with $25 \mu \mathrm{L}$ of sterile $1 \times \mathrm{PBS}(n=7)$. The syringe was stabilized by a mechanical holder (VisualSonics Inc., Toronto, ON, Canada). Following the ultrasound, mice were placed under a heat lamp for recovery (defined as when the mouse resumes normal activity, such as walking and responding), which typically occurred 10-20 min after removal from anesthesia. After recovery, mice were video monitored.

Intraperitoneal administration of LPS (73): pregnant B6 mice were intraperitoneally injected on $16.5 \mathrm{dpc}$ with $10 \mu \mathrm{g}$ of LPS (Escherichia coli 055:B5; Sigma-Aldrich) $(n=10)$ in $200 \mu \mathrm{L}$ of PBS using a 26-G needle. Controls were injected with $200 \mu \mathrm{L}$ of sterile $1 \times \mathrm{PBS}(n=8)$. Mice were video monitored.

\section{Video Monitoring}

Pregnancy parameters including the rates of preterm birth and pup mortality were recorded via video camera (Sony Corporation, Tokyo, Japan). Preterm birth was defined as delivery occurring before $18.0 \mathrm{dpc}$, and its rate was represented by the percentage of females delivering preterm among the total number of mice injected. The rate of pup mortality for each litter was defined as the proportion of delivered pups found dead among the total litter size. Neonatal survival was recorded 1 week postpartum.

\section{Serum and Tissue Collection From Dams}

Pregnant B6 mice were intraperitoneally or intra-amniotically injected with either LPS or PBS on $16.5 \mathrm{dpc}$, as described previously. On $17.5 \mathrm{dpc}$, mice were euthanized, and peripheral blood was collected by cardiac puncture and placed into a $1.5 \mathrm{~mL}$ safelock Eppendorf tube (Fisher Scientific, Hanover Park, IL, USA).
Serum ( $n=10$ each) was separated from the maternal peripheral blood and stored at $-20^{\circ} \mathrm{C}$ until analysis. Animal dissection to obtain the fetal lung ( $n=10-21$ each) and amniotic fluid ( $n=5-14$ each) was performed. The amniotic fluid was also collected from each amniotic sac with a $26-\mathrm{G}$ needle and placed into a $0.5 \mathrm{~mL}$ safe-lock Eppendorf tube (Fisher Scientific). Amniotic fluid samples were centrifuged at $1,300 \times g$ for $10 \mathrm{~min}$ at $4^{\circ} \mathrm{C}$ and the supernatant was separated and stored at $-20^{\circ} \mathrm{C}$ until analysis.

\section{Ex4 Treatment}

Pregnant B6 mice were intraperitoneally injected with $30 \mu \mathrm{g} /$ $\mathrm{kg}$ of Ex4 (Enzo Life Sciences, Ann Arbor, MI, USA) diluted in sterile $1 \times$ PBS $6 \mathrm{~h}$ after intraperitoneal $(n=10)$ or intra-amniotic $(n=8)$ administration of LPS. Control pregnant mice were intraperitoneally injected with $30 \mu \mathrm{g} / \mathrm{kg}$ of $\operatorname{Ex} 4(n=5)$ on 16.5 dpc. Pregnant mice were also injected with LPS alone either intraperitoneally $(10 \mu \mathrm{g} / 200 \mu \mathrm{L}, n=10)$ or intra-amniotically (10 ng/25 $\mu \mathrm{L}, n=8$ ) on $16.5 \mathrm{dpc}$, and control mice received an intraperitoneal $(200 \mu \mathrm{L}, n=8)$ or intra-amniotic $(25 \mu \mathrm{L}, n=7)$ injection of $1 \times$ PBS alone on $16.5 \mathrm{dpc}$. Lower doses of Ex4 were also tested (10 and $20 \mu \mathrm{g} / \mathrm{kg}$ ); however, these did not have protective effects (data not shown).

\section{Fluorescent In Vivo Imaging to Detect Ex4}

Pregnant B6 mice were injected intraperitoneally with $30 \mu \mathrm{g} / \mathrm{kg}$ of Ex4 (Fluorescein-TRP25-Exendin-4, FLEX) (cat \# AS-63899, Anaspec Inc., Fremont, CA, USA) $6 \mathrm{~h}$ after the intraperitoneal administration of LPS $(n=3)$. Control mice were injected with LPS, FLEX, or $200 \mu \mathrm{L}$ of PBS alone at $16.5 \mathrm{dpc}(n=3 \mathrm{each})$. One hour after the second injection, the uterus, placenta, decidua, fetal membranes, and fetus were collected to perform imaging using an IVIS Spectrum (Caliper Life Sciences, Hopkinton, MA, USA) in epifluorescence mode.

\section{Plasma and Tissue Collection From Neonates}

Pregnant B6 mice were injected intraperitoneally with $30 \mu \mathrm{g} / \mathrm{kg}$ of Ex4 $6 \mathrm{~h}$ after intraperitoneal administration of LPS $(n=3)$. Control pregnant mice were injected with $200 \mu \mathrm{L}$ of $1 \times$ PBS or Ex4 alone ( $n=3$ each). Thriving neonates ( $n=12-14$ per group) were euthanized at 15 days of age and the brain, thymus, lung, spleen, liver, and small and large intestine were collected. Plasma was also separated from the neonatal peripheral blood and stored at $-20^{\circ} \mathrm{C}$ until analysis. For RNA studies, the neonatal brain, lung, liver, and small intestine were placed into RNAlater Stabilization Solution (Invitrogen by Thermo Fisher Scientific, Baltics UAB, Lithuania) according to the manufacturer's instructions. For leukocyte isolation, the neonatal thymus, lung, spleen, liver, and large intestine were utilized.

\section{Chemokine/Cytokine Concentrations}

Maternal serum, neonatal plasma, and amniotic fluid samples were assessed for chemokine/cytokine concentrations. The ProcartaPlex Mouse Cytokine \& Chemokine Panel 1A 36-plex (Invitrogen by Thermo Fisher Scientific, Vienna, Austria) was used to measure the concentrations of IFN $\alpha$, IFN $\gamma$, IL-12p70, 
IL-1 $\beta$, IL-2, TNF $\alpha$, GM-CSF, IL-18, IL-17A, IL-22, IL-23, IL-27, IL-9, IL-15/IL-15R, IL-13, IL-4, IL-5, IL-6, IL-10, Eotaxin (CCL11), IL-28, IL-3, LIF, IL-1 $\alpha$, IL-31, GRO- $\alpha$ (CXCL1), MIP-1 $\alpha$ (CCL3), IP-10 (CXCL10), MCP-1 (CCL2), MCP-3 (CCL7), MIP$1 \beta$ (CCL4), MIP-2 (CXCL2), RANTES (CCL5), G-CSF, M-CSF, and ENA-78 (CXCL5) in the serum, plasma, and amniotic fluid samples, according to the manufacturer's instructions. Plates were read using the Luminex 100 SystemFill (Luminex, Austin, TX, USA), and analyte concentrations were calculated with ProcartaPlex Analyst 1.0 Software from Affymetrix, San Diego, CA, USA. The sensitivities of the assays were $3.03 \mathrm{pg} / \mathrm{mL}$ (IFN $\alpha)$, $0.09 \mathrm{pg} / \mathrm{mL}$ (IFN $\gamma$ ), $0.21 \mathrm{pg} / \mathrm{mL}$ (IL-12p70), $0.14 \mathrm{pg} / \mathrm{mL}$ (IL-1 $\beta$ ), $0.10 \mathrm{pg} / \mathrm{mL}$ (IL-2), $0.39 \mathrm{pg} / \mathrm{mL}$ (TNF $\alpha), 0.19 \mathrm{pg} / \mathrm{mL}$ (GM-CSF), $9.95 \mathrm{pg} / \mathrm{mL}$ (IL-18), $0.08 \mathrm{pg} / \mathrm{mL}$ (IL-17A), $0.24 \mathrm{pg} / \mathrm{mL}$ (IL-22), $2.21 \mathrm{pg} / \mathrm{mL}$ (IL-23), $0.34 \mathrm{pg} / \mathrm{mL}$ (IL-27), $0.28 \mathrm{pg} / \mathrm{mL}$ (IL-9), $0.42 \mathrm{pg} / \mathrm{mL}$ (IL-15/IL-15R), $0.16 \mathrm{pg} / \mathrm{mL}$ (IL-13), $0.03 \mathrm{pg} / \mathrm{mL}$ (IL-4), $0.32 \mathrm{pg} / \mathrm{mL}$ (IL-5), $0.21 \mathrm{pg} / \mathrm{mL}$ (IL-6), $0.69 \mathrm{pg} / \mathrm{mL}$ (IL-10), $0.01 \mathrm{pg} / \mathrm{mL}$ (Eotaxin), $20.31 \mathrm{pg} / \mathrm{mL}$ (IL-28), $0.11 \mathrm{pg} / \mathrm{mL}$ (IL-3), $0.28 \mathrm{pg} / \mathrm{mL}$ (LIF), $0.32 \mathrm{pg} / \mathrm{mL}$ (IL-1 $\alpha), 0.45 \mathrm{pg} / \mathrm{mL}$ (IL-31), $0.05 \mathrm{pg} / \mathrm{mL}$ (GRO- $\alpha), 0.13 \mathrm{pg} / \mathrm{mL}$ (MIP-1 $\alpha), 0.26 \mathrm{pg} / \mathrm{mL}$ (IP-10), $3.43 \mathrm{pg} / \mathrm{mL}$ (MCP-1), $0.15 \mathrm{pg} / \mathrm{mL}$ (MCP-3), $1.16 \mathrm{pg} / \mathrm{mL}$ (MIP-1 $\beta$ ), $0.37 \mathrm{pg} / \mathrm{mL}$ (MIP-2), $0.35 \mathrm{pg} / \mathrm{mL}$ (RANTES), $0.19 \mathrm{pg} / \mathrm{mL}$ (G-CSF), $0.02 \mathrm{pg} / \mathrm{mL}$ (M-CSF), and $5.67 \mathrm{pg} / \mathrm{mL}$ (ENA-78). Inter-assay and intra-assay coefficients of variation were less than $10 \%$.

\section{RNA Isolation, cDNA Synthesis, and Reverse Transcription Quantitative Polymerase Chain Reaction Analysis}

Total RNA was isolated from fetal ( $17.5 \mathrm{dpc}$ ) and neonatal ( 15 days of age) tissues using QIAshredders, RNase-Free DNase Sets, and RNeasy Mini Kits (all from Qiagen, Hilden, Germany), according to the manufacturer's instructions. RNA concentrations and purity were assessed with the NanoDrop 1000 spectrophotometer (Thermo Scientific, Wilmington, DE, USA), and RNA integrity was evaluated with the Bioanalyzer 2100 (Agilent Technologies, Wilmington, DE, USA). Complementary (c)DNA was synthesized using SuperScript III First-Strand Synthesis SuperMix (Invitrogen by Thermo Fisher Scientific, Carlsbad, CA, USA). Gene expression profiling was performed on the BioMark ${ }^{\mathrm{TM}}$ System for high-throughput RT-qPCR (Fluidigm, San Francisco, CA, USA) with the TaqMan ${ }^{\circledR}$ gene expression assays (Applied Biosystems, Life Technologies Corporation, Foster City, CA, USA) listed in Table S1 in Supplementary Material.

\section{Leukocyte Isolation}

The neonatal lung, liver, and large intestine were cut into small pieces using fine scissors and enzymatically digested with StemPro Cell Dissociation Reagent (Accutase, Life Technologies, Grand Island, NY, USA) for $10 \mathrm{~min}$ at $37^{\circ} \mathrm{C}$. The spleen and thymus were gently dissociated using two glass slides to prepare a leukocyte suspension as previously described (74). Leukocyte suspensions were filtered using a $35 \mu \mathrm{m}$ cell strainer (Falcon, Tamaulipas, Mexico) and washed with $1 \times$ PBS.

\section{Immunophenotyping}

Leukocyte suspensions from the neonatal tissues were stained using LIVE/DEAD Fixable Blue Dead Cell Stain Kit (Life
Technologies) prior to incubation with extracellular and intracellular mAbs. Leukocyte suspensions were centrifuged at $1,250 \times g$ for $7 \mathrm{~min}$ at $4^{\circ} \mathrm{C}$ and cell pellets were incubated for $10 \mathrm{~min}$ with the CD16/CD32 mAb (FcgIII/II Receptor; BD Biosciences, San Jose, CA, USA) and subsequently incubated with specific extracellular and intracellular fluorochrome-conjugated anti-mouse mAbs (Table S2 in Supplementary Material) for $30 \mathrm{~min}$. After extracellular staining, the cells were washed with fluorescenceactivated cell sorting (FACS) buffer (bovine serum albumin $0.1 \%$, sodium azide $0.05 \%, 1 \times$ PBS) to remove excess Ab. For immunophenotyping of macrophages and neutrophils, following the extracellular staining, the cells from the neonatal lung, liver, and large intestine were fixed and permeabilized using the BD Cytofix/Cytoperm fixation and permeabilization solution (BD Biosciences). For immunophenotyping of Tregs, following the extracellular staining, the cells from the neonatal thymus and spleen were fixed and permeabilized using the Foxp3/ Transcription Factor Staining Buffer Set (eBioscience, San Diego, CA, USA) prior to intranuclear Foxp3 staining.

Leukocyte subsets were gated within the viability gate. Immunophenotyping included identification of (1) macrophages $(\mathrm{CD} 11 \mathrm{~b}+\mathrm{F} 4 / 80+)$ and their M1/M2 phenotypes by the expression of IL-10 and iNOS; (2) neutrophils (CD11b+ Ly6G+) and their anti- and pro-inflammatory phenotypes by the expression of IL-10 and iNOS; and (3) CD4+ and CD8+ Tregs (CD3+ CD4+ CD25+ FoxP3+ and CD3+ CD8+ CD25+ FoxP3+ cells, respectively).

The total number of specific leukocytes was determined using Count Bright absolute counting beads (Molecular Probes, Eugene, OR, USA). As a control for cellular autofluorescence, unstained cells were also treated in this same manner. Stained and unstained cell suspensions were re-suspended in $0.5 \mathrm{~mL}$ of FACS buffer and acquired using an LSRFortessa flow cytometer and FACSDiva 8.0 software (BD Biosciences). Data were analyzed using FlowJo software version 10 (Tree Star, Ashland, OR, USA).

\section{Statistical Analysis}

Observational mouse data were analyzed using IBM SPSS, version 19.0, and all other analysis was performed with GraphPad Prism version 5. For rates of preterm birth and pup mortality, the statistical significance of group comparisons was assessed using Mann-Whitney $U$ test. For RT-qPCR arrays, $-\Delta C t$ values were determined using multiple reference genes (Gusb, Hsp90ab1, Gapdh, and $A c t b$ ) averaged within each sample to determine gene expression levels. A heat map was created for the group mean expression matrix (gene $\times$ group mean), with individual gene expression level being standardized first. The heat map represents the $Z$-scores of the mean $(-\Delta \mathrm{Ct})$ and the hierarchical clustering using correlation distance. For flow cytometry data, the statistical significance of group comparisons was assessed using MannWhitney $U$ tests. A $p$-value $<0.05$ was considered significant.

\section{RESULTS}

\section{Models of Inflammation-Induced Preterm Birth and Adverse Neonatal Outcomes}

We first compared our two previously established models of inflammation-induced preterm birth: systemic administration of 
LPS via intraperitoneal injection (maternal inflammatory response model, MIR) and local administration of LPS via intra-amniotic injection (fetal inflammatory response model, FIR) (73). We injected mice intra-amniotically $(100 \mathrm{ng} / 25 \mu \mathrm{L})$ or intraperitoneally $(10 \mu \mathrm{g} / 200 \mu \mathrm{L})$ with LPS (or PBS controls) and observed pregnancy outcomes (Figure 1A). Both the MIR and FIR models resulted in a high rate of preterm birth ( 80 and $87.5 \%$, respectively) while all of the controls injected with PBS delivered at term (Figures 1B,C). The rate of pup mortality at birth was greater than $85 \%$ in both the MIR and FIR models, which was significantly higher than that of controls (Figures 1D,E). At 1 week of age, no pups from dams that received either systemic or local administration of LPS survived (Figures 1F,G). These results demonstrate that a large LPS insult administered systemically or a lower dose given intra-amniotically induces adverse pregnancy and neonatal outcomes.

\section{The Maternal Cytokine Response in the MIR and FIR Models}

Next, we measured cytokine concentrations in the maternal circulation to evaluate the systemic inflammatory response in both the MIR and FIR models (Figure 2A). In the MIR model, there were significantly higher serum concentrations of 30 cytokines compared with PBS controls (Figures 2B-D,F-S; Figures S1A-D,F-J,L,N-P in Supplementary Material). In the FIR model, however, only seven cytokine concentrations were higher compared with controls (Figures 2B,D,F,G,O,S; Figure S1O in Supplementary Material). Interestingly, from the 34 cytokine concentrations reported herein, 25 of these were significantly higher in the MIR model than those in the FIR model (Figures 2B-D,F-S; Figures S1A,D,F,H-J,N-P in Supplementary Material). Therefore, the MIR model is characterized by a stronger maternal cytokine response than the FIR model.

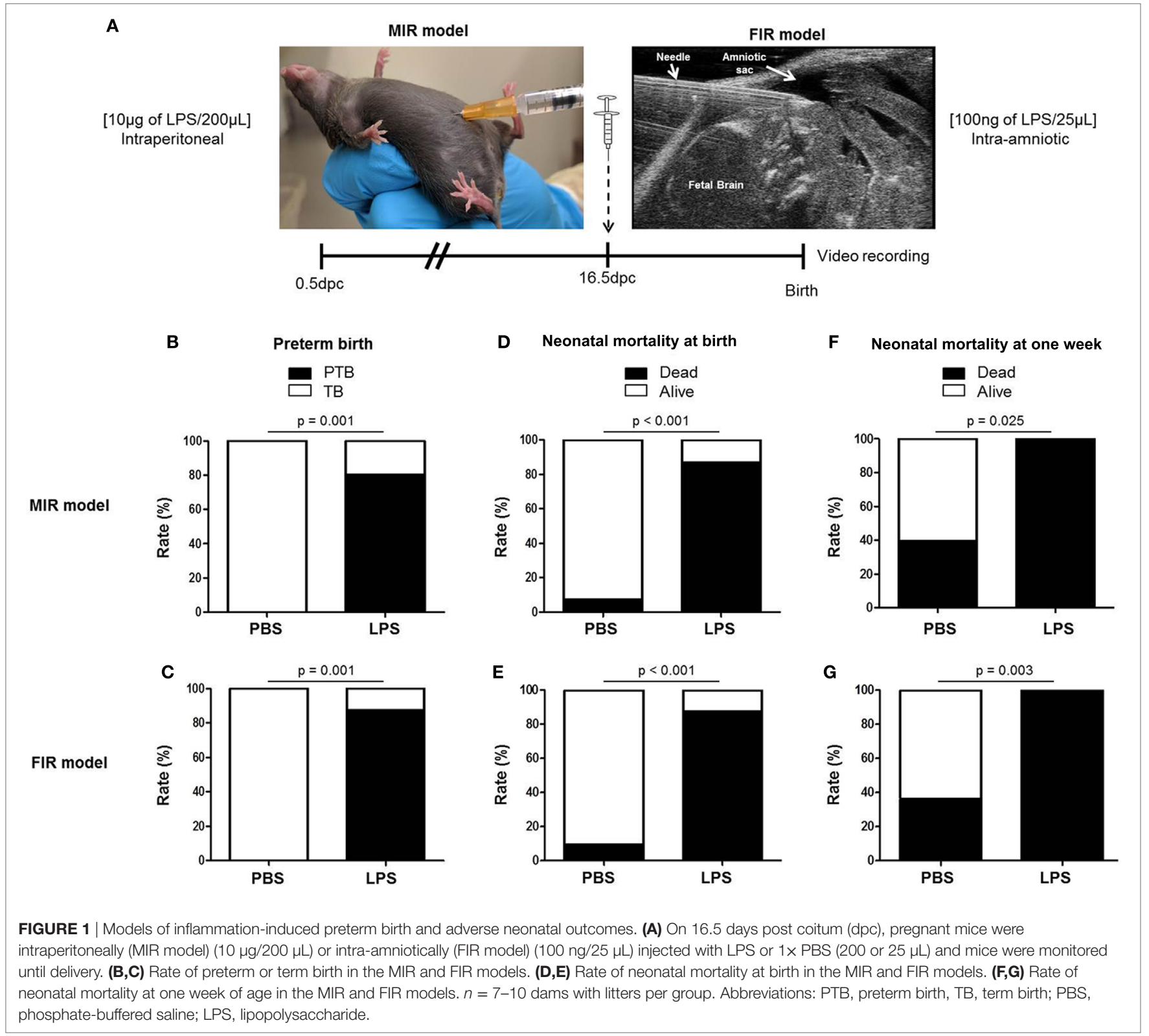




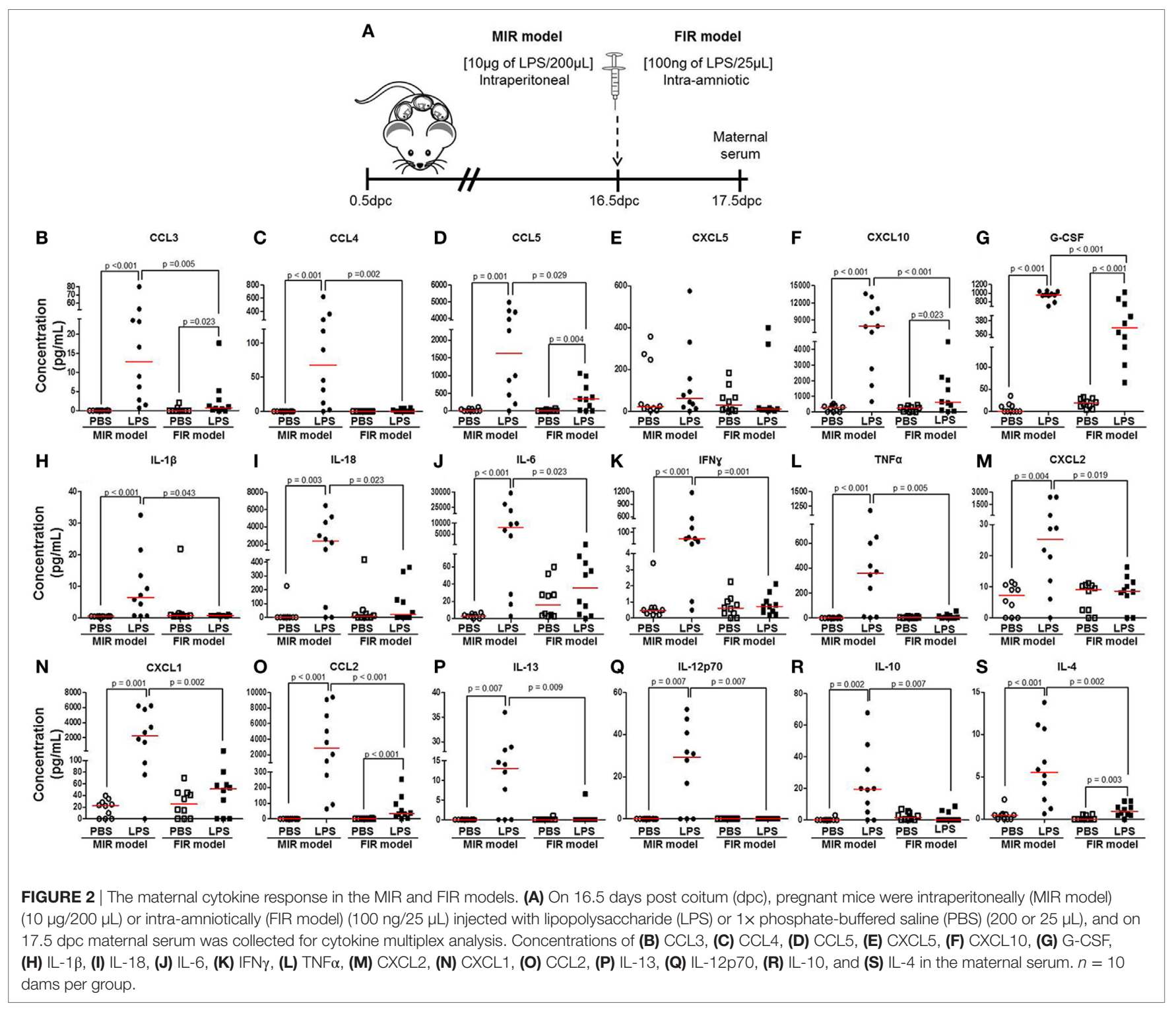

\section{The Fetal Cytokine Response in the MIR and FIR Models}

The fetal inflammatory response is associated with elevated IL-6 in the amniotic fluid $(32,33)$. Therefore, we collected amniotic fluid from the MIR and FIR models and measured cytokine concentrations (Figure 3A, left panel). No apparent differences were found between fetuses of dams injected with LPS intraperitoneally (MIR model) and their control counterparts; yet, fetuses of dams injected with LPS intra-amniotically (FIR model) seemed smaller and friable compared with those from PBS injected controls (Figure 3A, right panel). We found higher concentrations of 16 cytokines in the amniotic fluid in the MIR model when compared with its control (Figures 3B-G,R; Figures S2B,E,H-N in Supplementary Material). In the FIR model, we similarly detected an elevation in the amniotic fluid concentrations of 13 cytokines compared with its control (Figures 3B-M,R). However, the concentrations of 15 amniotic fluid cytokines were significantly higher in the FIR model than in the MIR model
(Figures 3B-F,H-Q). Amniotic fluid concentrations of IL-4 were unchanged in the MIR and FIR models compared to their controls, and there was no significant difference when comparing the two models (Figure 3S). These results indicate that the fetal inflammatory response is more severe when the insult is given intra-amniotically than when given systemically.

\section{Inflammatory Gene Expression in the Fetal Lung}

Intra-amniotic inflammation is associated with fetal lung damage (75-77) and bronchopulmonary disorder (78-81). We then evaluated the expression of inflammation-associated genes in fetal lungs in both the MIR and FIR models (Figure 4A). No apparent differences were found between the lungs from fetuses of dams intraperitoneally injected with LPS (MIR model) compared with their controls; yet, the lungs from fetuses of dams with FIR seemed pallid compared with controls (Figure 4A). The heatmap array shown in Figure 4B indicated that, in the MIR model, there 


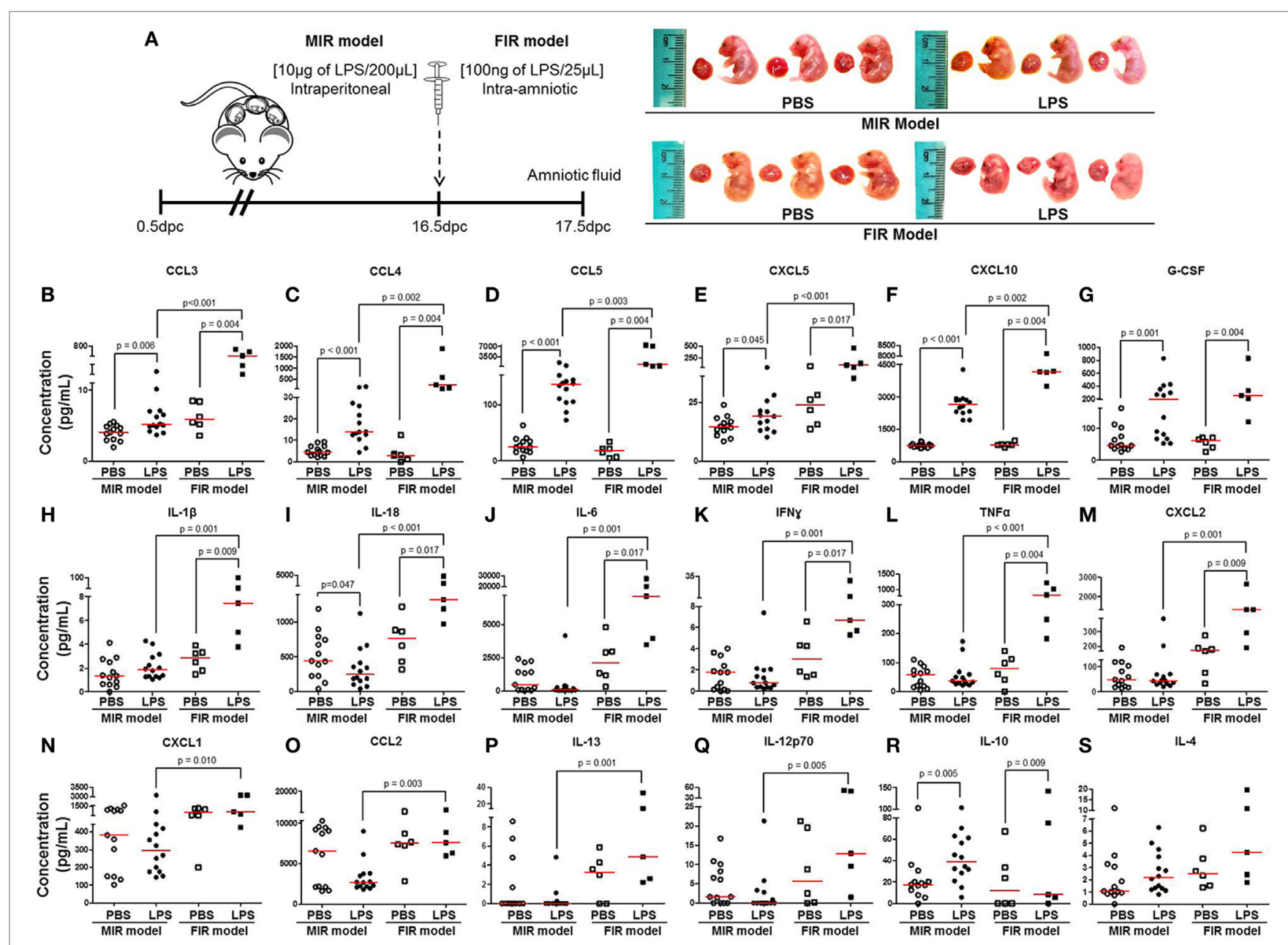

FIGURE 3 | The fetal inflammatory response in the MIR and FIR models. (A) On 16.5 days post coitum (dpc), pregnant mice were intraperitoneally (MIR model)

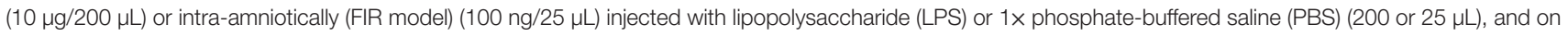
$17.5 \mathrm{dpc}$ amniotic fluid was collected for cytokine multiplex analysis. Photographs of fetuses from dams with MIR or FIR are shown. Concentration of (B) CCL3,

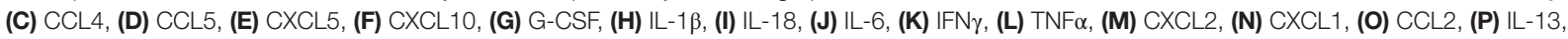

(Q) IL-12p70, (R) IL-10, and (S) IL-4 in the amniotic fluid. $n=5-14$ dams per group.

is a downregulation of inflammation-related genes in the fetal lungs, whereas in the FIR model, there is an upregulation of such genes (Figure 4B). When the expression of specific inflammatory genes in the fetal lung was plotted, we observed that Illb, Il6, Ccl2, $\mathrm{Ccl} 3, \mathrm{Ccl} 5$, and $\mathrm{Cxcl} 1$ were significantly upregulated in the FIR model compared with its control (Figures $4 \mathbf{C}-\mathbf{H}$ ). In the MIR model, however, only $\mathrm{Ccl} 3$ was upregulated in the fetal lungs compared with its control (Figure 4F). Indeed, the expression of $\mathrm{Ccl} 2$ and $\mathrm{Ccl5}$ was downregulated in the MIR model (Figures 4E,G). Together, these data demonstrate that intra-amniotic microbial products can cause an overexpression of inflammation-related genes in the fetal lungs, whereas maternal systemic inflammation seems to have the opposite effect.

\section{Treatment With Ex4 Improves Adverse Pregnancy and Neonatal Outcomes}

In order to dampen the inflammation caused in the MIR and FIR models, we investigated whether an anti-inflammatory peptide, Ex4 $(63-66,69,70)$, could reduce or prevent adverse pregnancy and neonatal outcomes (Figure 5A). Ex4 treatment caused a $10 \%$ reduction in the rate of preterm birth in the MIR model compared with dams that received only LPS (Figure 5B). Pups from the MIR model treated with Ex4 had a similar rate of mortality at birth compared with those without Ex4 treatment (Figure 5C). Interestingly, live-born pups from the MIR model which had received Ex4 treatment continued to thrive, whereas those born to dams without treatment died shortly after birth (Figure 5D).

In the FIR model, dams treated with Ex4 had a 37.5\% decrease in the rate of preterm birth (Figure 5E). In addition, pups from the FIR model treated with Ex4 had a $26.3 \%$ decrease in mortality at birth compared with those born to untreated dams (Figure 5F); however, none of the pups from the FIR model survived to 1 week of age regardless of Ex4 treatment (Figure 5G).

In both the MIR and FIR models, treatment with Ex4 alone did not induce adverse pregnancy or neonatal outcomes (Figures 5B-G). Mice that received an intraperitoneal or 


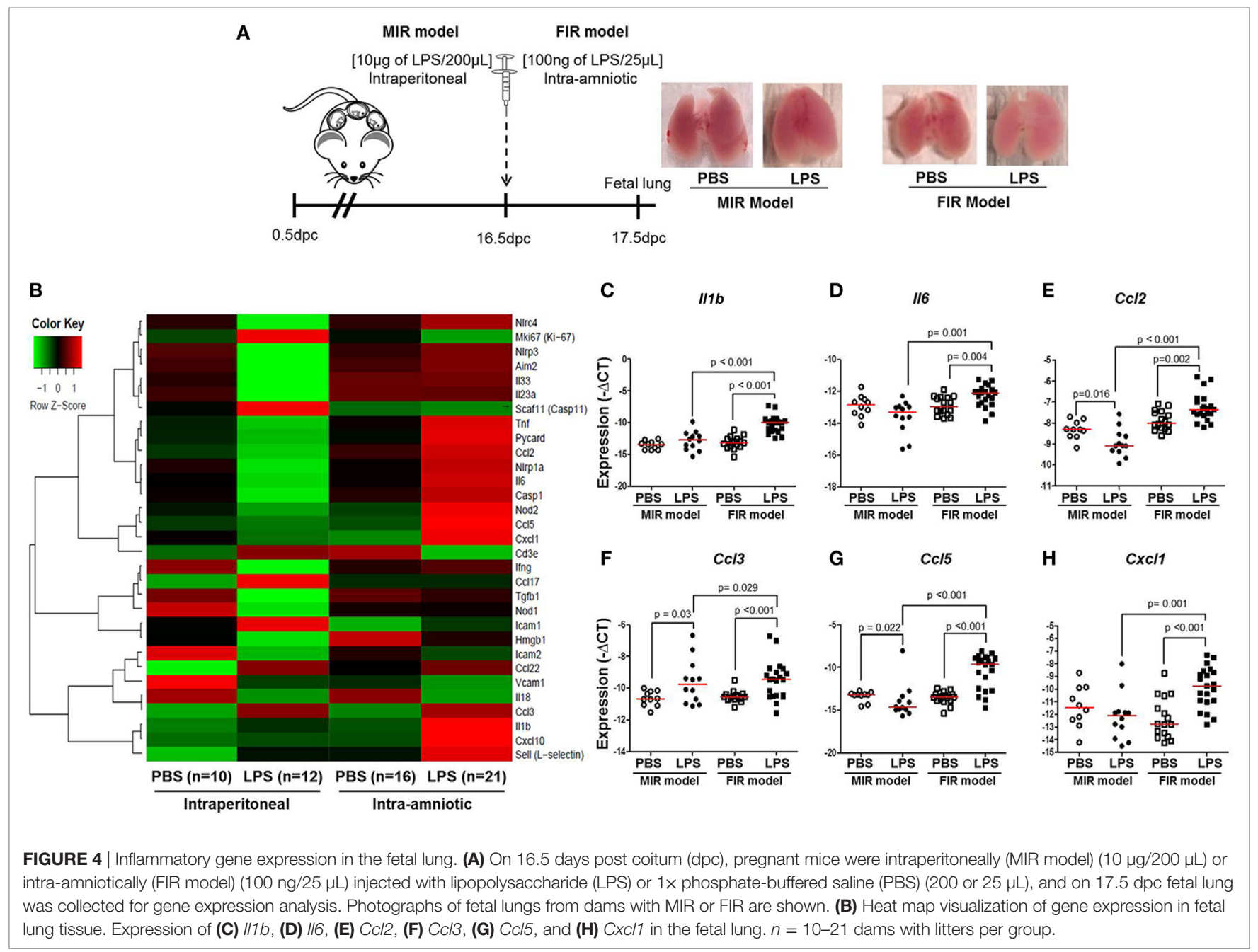

intra-amniotic injection of $1 \times$ PBS did not present adverse pregnancy or neonatal outcomes (data not shown).

Collectively, these results show that Ex4 treatment can modestly reduce the rate of preterm delivery in dams with MIR or FIR. Importantly, Ex4 treatment can alleviate adverse neonatal outcomes in dams with systemic maternal inflammation but not in those with intra-amniotic inflammation.

\section{Ex4 Is Localized in the Uterus and Maternal-Fetal Interface}

Since treatment with Ex4 had beneficial effects in the MIR model, we next investigated the localization of this peptide in the maternal and fetal tissues using a fluorescence-labeled Ex4 (FLEX), which fluoresces after binding to the GLP-1 receptor (82) (Figure 6A). No signal was observed in the control tissues from mice injected with PBS or LPS alone (Figure 6B). Ex4 was strongly detected in the uterus from mice injected with LPS and FLEX (Figure 6B). A few traces of Ex4 were also detected in the decidua and fetal membranes from mice injected with LPS and FLEX (Figure 6B). However, Ex4 was not detected in any of the maternal or fetal tissues in mice injected with FLEX alone
(Figure 6B). These findings suggest that systemic inflammation facilitates the diffusion of Ex4 through the uterus and the maternal-fetal interface.

\section{Neonates Born to Dams With Systemic Inflammation and Treated With Ex4 Display a Similar Cytokine Profile to Healthy Neonates}

Neonates born to dams with MIR and treated with Ex4 were indistinguishable from neonates born to control dams injected with Ex4 (data not shown) or PBS alone (Figure 7A, right panel). However, whether the immune system of these thriving pups was comparable to healthy neonates was unknown. We therefore compared the cytokine and cellular immune responses between neonates born to Ex4-treated dams with MIR and those from control dams. First, the plasma cytokine profile of 15-day-old neonates was determined (Figure 7A, left panel). Neonates born to dams with MIR which received Ex4 treatment had comparable plasma cytokine concentrations (31 of 35 cytokines) to healthy neonates (pups born to dams injected with PBS alone) (Figures 7B,C,E,G-K,M-P,R,S; Figures S3A-Q in 


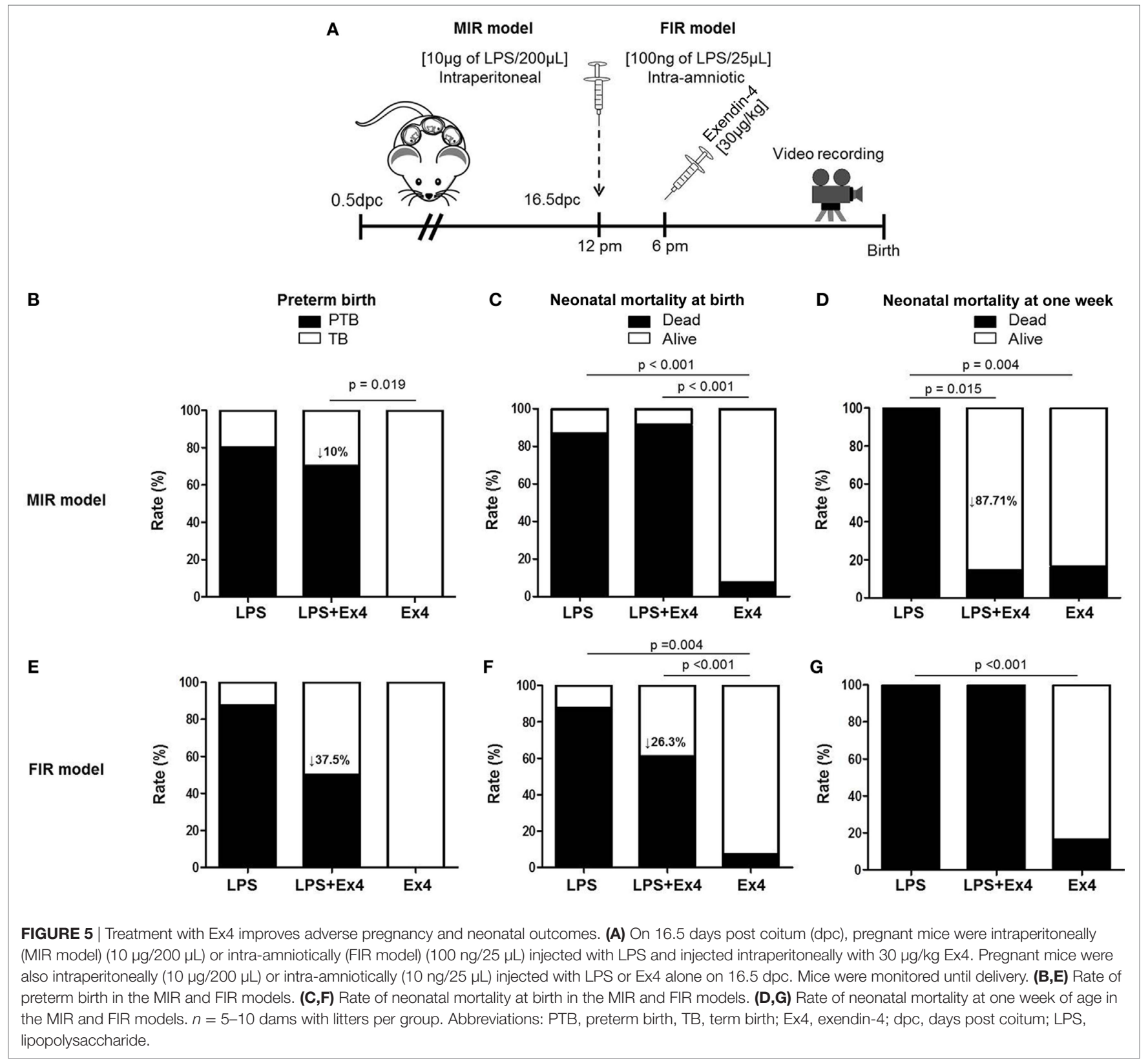

Supplementary Material). Indeed, the plasma cytokine concentrations of CCL5, CXCL10, TNF $\alpha$, and IL-12p70 were decreased in neonates born to dams with MIR which received Ex4 treatment (Figures 7D,F,L,Q) compared with healthy pups. Healthy pups treated with Ex4 alone had comparable, or even lower, plasma cytokine concentrations to healthy pups from dams injected with PBS alone (Figures S4A-R in Supplementary Material).

Next, we determined the expression of inflammation-related genes in the neonatal brain, lung, liver, and small intestine (Figure 7A). The expression of $\mathrm{Ill} 1 \mathrm{~b}, \mathrm{Il} 6, \mathrm{Ccl} 2, \mathrm{Ccl} 3, \mathrm{Ccl} 5$, and Cxcl1 in the brain, lung, liver, and small intestine from pups born to MIR dams which received Ex4 treatment was comparable to that of healthy pups (Figures 8A-F). No differences in the expression of such genes were observed between healthy pups born to dams injected with PBS (controls) or Ex4 alone (Figures S5A-X in Supplementary Material).

Collectively, these data show that Ex4 has anti-inflammatory properties in dams with MIR, which results in thriving and healthy neonates.

\section{Ex4 Treatment Induces an M1 $\rightarrow$ M2 Macrophage Polarization in the Neonate}

The innate immune system has a central role in fetal and neonatal life $(83,84)$; therefore, we investigated whether neonates born to dams with MIR and treated with Ex4 had effects on lung, liver, and large intestine M1/M2 macrophage phenotypes. Macrophage immunophenotyping was performed in neonatal 


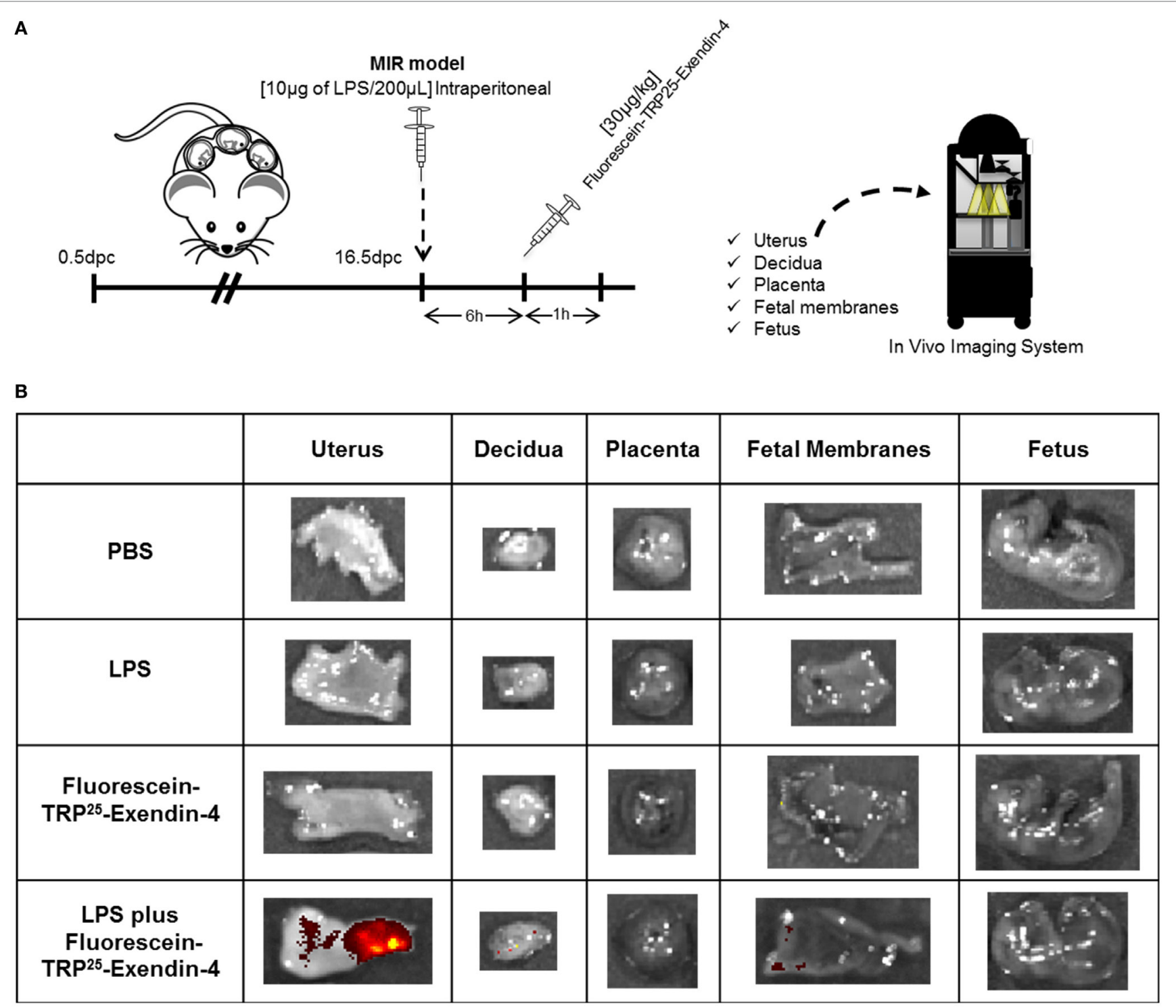

FIGURE 6 | Exendin-4 is localized in the uterus and maternal-fetal interface. (A) On 16.5 days post coitum (dpc), pregnant mice were intraperitoneally injected with:

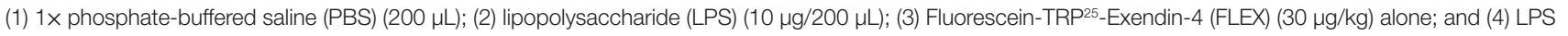
followed by treatment with FLEX (30 $\mu \mathrm{g} / \mathrm{kg})$. Imaging was performed $1 \mathrm{~h}$ after the second injection. (B) Representative images taken with the In Vivo Imaging System showing the fluorescence of FLEX in the uterus, decidua, placenta, fetal membranes, and fetus. $n=3$ per group.

tissues (Figure 9A). The numbers of macrophages in the neonatal lung and liver were significantly reduced in neonates born to MIR dams which received Ex4 treatment when compared with those from controls (Figures 9B,E). The number of macrophages in the large intestine from neonates born to dams with MIR and treated with Ex4 was comparable to that of healthy pups (Figure $9 \mathbf{H}$ ).

Next, M1-like (CD11b+ F4/80+ iNOS+) and M2-like (CD11b+ F4/80+ IL-10+) macrophages were immunophenotyped in these tissues (Figure 9A), as previously reported (49, $50,54,55)$. There was an increase in the number of M2-like macrophages in the lung and large intestine of neonates born to MIR dams with Ex4 treatment compared with controls (Figures 9C,I). The number of M2-like macrophages in the liver from neonates born to dams with MIR and treated with Ex4 was comparable to that of healthy pups (Figure 9F). Conversely, there was a decrease in the number of M1-like macrophages in the liver of neonates born to MIR dams with Ex4 treatment (Figure 9G). The number of M1-like macrophages in the lung and large intestine from neonates born to dams with MIR and treated with Ex4 was comparable to that of healthy pups (Figures 9D,J). Treatment of dams with Ex4 alone caused an M2 macrophage polarization in the neonatal tissues (Figures S6A-I in Supplementary Material). Taken together, these results indicate that Ex4 treatment of dams with MIR decreases the overall number of macrophages in the neonatal tissues, while promoting an M1 $\rightarrow$ M2 macrophage polarization. 


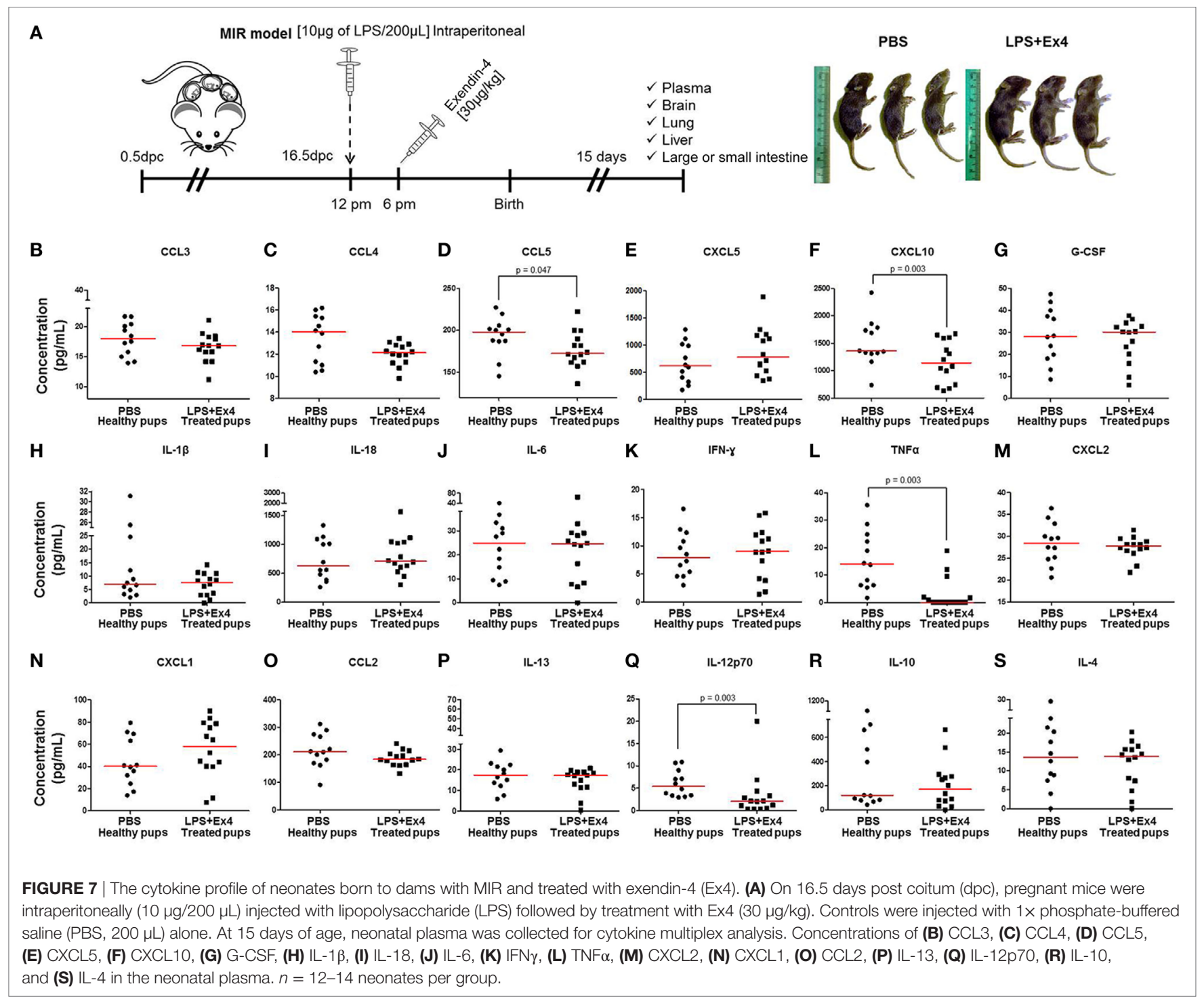

\section{Ex4 Treatment Induces a Neutrophil Polarization in the Neonate}

We next determined the total numbers of neutrophils (CD11b+ Ly6G+) as well as their expression of pro-inflammatory (iNOS) and anti-inflammatory (IL-10) cytokines in the neonatal lung, liver, and large intestine (Figure 10A). The total numbers of neonatal neutrophils were increased in the lung and large intestine of neonates born to MIR dams with Ex4 treatment when compared with PBS controls (Figures 10B,H). The number of neutrophils in the liver from neonates born to dams with MIR and treated with Ex4 was comparable to that of healthy pups (Figure 10E).

Neutrophil immunophenotyping in neonatal tissues was also performed (Figure 10A). There was an increase in the number of IL-10-expressing neutrophils in the lung, liver, and large intestine of neonates born to MIR dams with Ex4 treatment compared with controls (Figures 10C,F,I). By contrast, there was a decrease in the number of iNOS-expressing neutrophils in the liver of neonates born to MIR dams with Ex4 treatment compared with healthy pups (Figure 10G). The number of iNOS-expressing neutrophils in the lung and large intestine from neonates born to dams with MIR and treated with Ex4 was comparable to that of healthy pups (Figures 10D,J). Treatment of dams with Ex4 alone only caused an increase of pro- and anti-inflammatory neutrophils in the neonatal large intestine (Figures S7G-I in Supplementary Material). These results show that Ex4 treatment of dams with MIR increases the number of anti-inflammatory neutrophils in the neonatal tissues.

\section{Ex4 Treatment Reduces Neonatal CD8+ Tregs}

Regulatory T cells (Tregs) play a central role in both the developing fetus and in the neonate $(83,85-89)$. We then determined whether Ex4 treatment of dams with MIR is altering neonatal Tregs subsets $(\mathrm{CD} 3+\mathrm{CD} 4+\mathrm{CD} 25+$ FoxP3+ and CD3+ CD8+ CD25+ FoxP3+ cells) in the neonatal spleen and thymus (Figure 11A). No differences were observed in the number of 


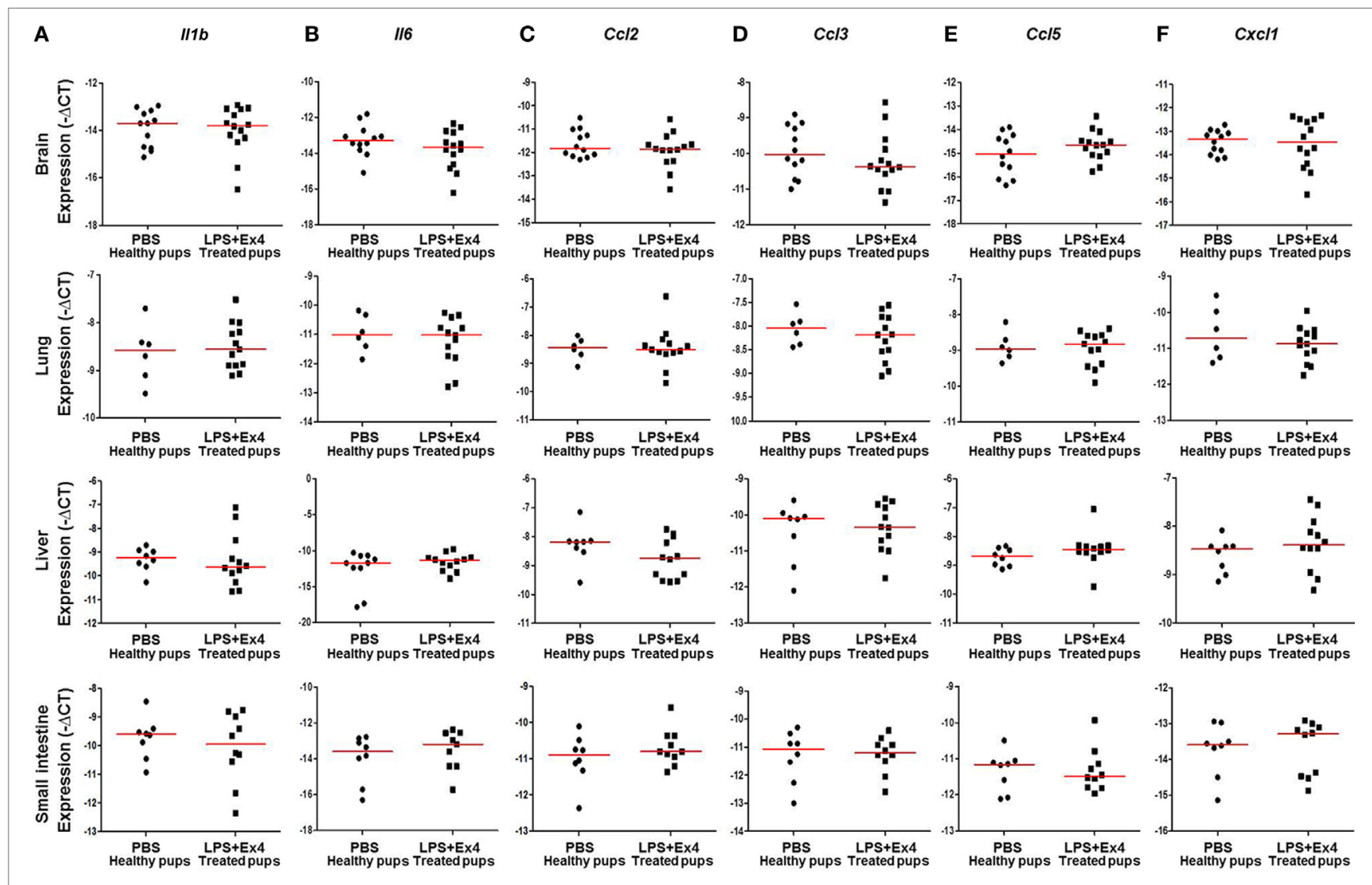

FIGURE 8 | Inflammatory gene expression in neonates born to dams with MIR and treated with exendin-4 (Ex4). On 16.5 days post coitum (dpc), pregnant mice were intraperitoneally $(10 \mu \mathrm{g} / 200 \mu \mathrm{L})$ injected with lipopolysaccharide (LPS) followed by treatment with Ex4 (30 $\mu \mathrm{g} / \mathrm{kg})$. Controls were injected with $1 \times$ phosphatebuffered saline (PBS, $200 \mu \mathrm{L}$ ) alone. At 15 days of age the neonatal brain, lung, liver, and small intestine were collected for gene expression analysis. Expression of (A) //1b, (B) //6, (C) Ccl2, (D) Cc/3, (E) Cc/5, and (F) Cxcl1 in the neonatal brain, lung, liver and small intestine. $n=12-14$ neonates per group.

splenic and thymic CD4+ Tregs between neonates born to Ex4 treated dams with MIR and healthy neonates (Figures 11B,C). The number of CD8+ Tregs was reduced in the spleen of neonates born to MIR dams with Ex4 treatment when compared with healthy neonates (Figure 11D); however, no differences were observed in thymic CD8+ Tregs (Figure 11E). No differences in the number of CD4+ and CD8+ Tregs were observed between neonates born to dams treated with Ex4 alone and those from PBS controls (Figures S8A-D in Supplementary Material). These results indicate that Ex4 may reduce neonatal inflammation by inhibiting the expansion of splenic CD8+ Tregs, which may have pro-inflammatory properties (90).

\section{DISCUSSION}

\section{Maternal and Fetal Inflammatory Responses in Preterm Labor}

The intra-amniotic administration of a microbial product derived from Gram-negative bacteria induced preterm birth and neonatal death, as previously reported (73). This model is similar to the subclinical syndrome of preterm birth since (a) a low dose of
LPS was injected, simulating the amniotic fluid concentrations of endotoxin found in women with spontaneous preterm labor (91); and (b) the intra-amniotic injection of low doses of LPS did not cause hypothermia, which is consistent with the fact that most of the intra-amniotic infections in women with spontaneous preterm labor occur in the absence of a temperature change (92, 93). Intra-amniotic infection is commonly associated with invasion of genital mycoplasmas, Gram-negative, and Gram-positive bacteria $(15,94-97)$ into the amniotic cavity. This infection can result in a maternal and/or fetal inflammatory response (15-17, $32,33,38,98-103)$. This is consistent with the findings reported herein, in which we observe that the intra-amniotic administration of a microbial product results in both a maternal and fetal inflammatory response.

The systemic administration of a microbial product induced a severe maternal cytokine response but a mild fetal cytokine response, which caused preterm birth and neonatal death. A systemic maternal inflammatory response is observed in women with clinical chorioamnionitis (18) and acute pyelonephritis $(104,105)$, both clinical conditions associated with preterm birth (106-109) and adverse neonatal outcomes (107, 108). However, clinical chorioamnionitis results from intra-amniotic infection 


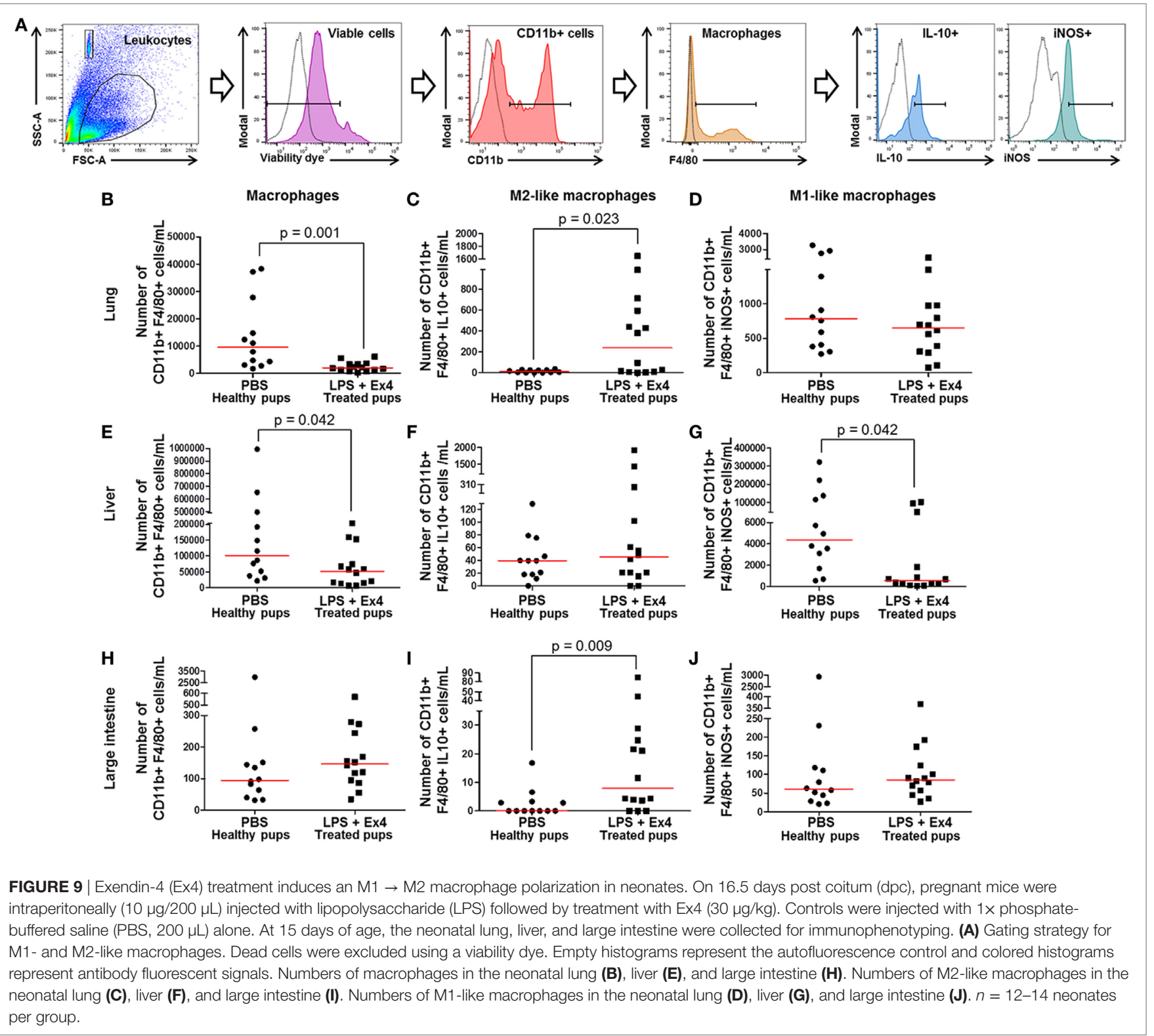

(15-18, 98), a condition which was not present in our model. On the other hand, acute pyelonephritis occurs independently of intra-amniotic infection and is not associated with a fetal inflammatory response (110), which resembles our MIR model.

\section{The Anti-Inflammatory Peptide Ex4 Rescues Inflammation-Induced Adverse Pregnancy and Neonatal Outcomes}

The adverse pregnancy and neonatal outcomes observed in the MIR model were ameliorated by treatment with Ex4. This is consistent with a previous report showing that a GLP-1 analog, such as Ex4, dampened inflammatory pathways in a rat model of sepsis (111). GLP-1 receptors are present in the maternal (112) and fetal tissues (112-114). Herein, we found that Ex4 was mainly localized in the uterus and to a lesser extent in the decidua. These findings suggest that treatment with $\mathrm{Ex} 4$ has anti-inflammatory effects in the MIR model by primarily targeting the maternal tissues. This scenario explains why treatment with Ex4 did not rescue the adverse neonatal outcomes in the FIR model. Treatment with Ex4, however, did reduce the rate of preterm birth and neonatal mortality at birth in the FIR model, suggesting that a combined approach that targets both the maternal and fetal tissues may be the optimal strategy.

Neonates born to dams with systemic inflammation and treated with Ex4 thrived and displayed plasma and tissue cytokine profiles comparable to healthy neonates. Previous studies have shown that the GLP-1 receptor is expressed in the fetal tissues 


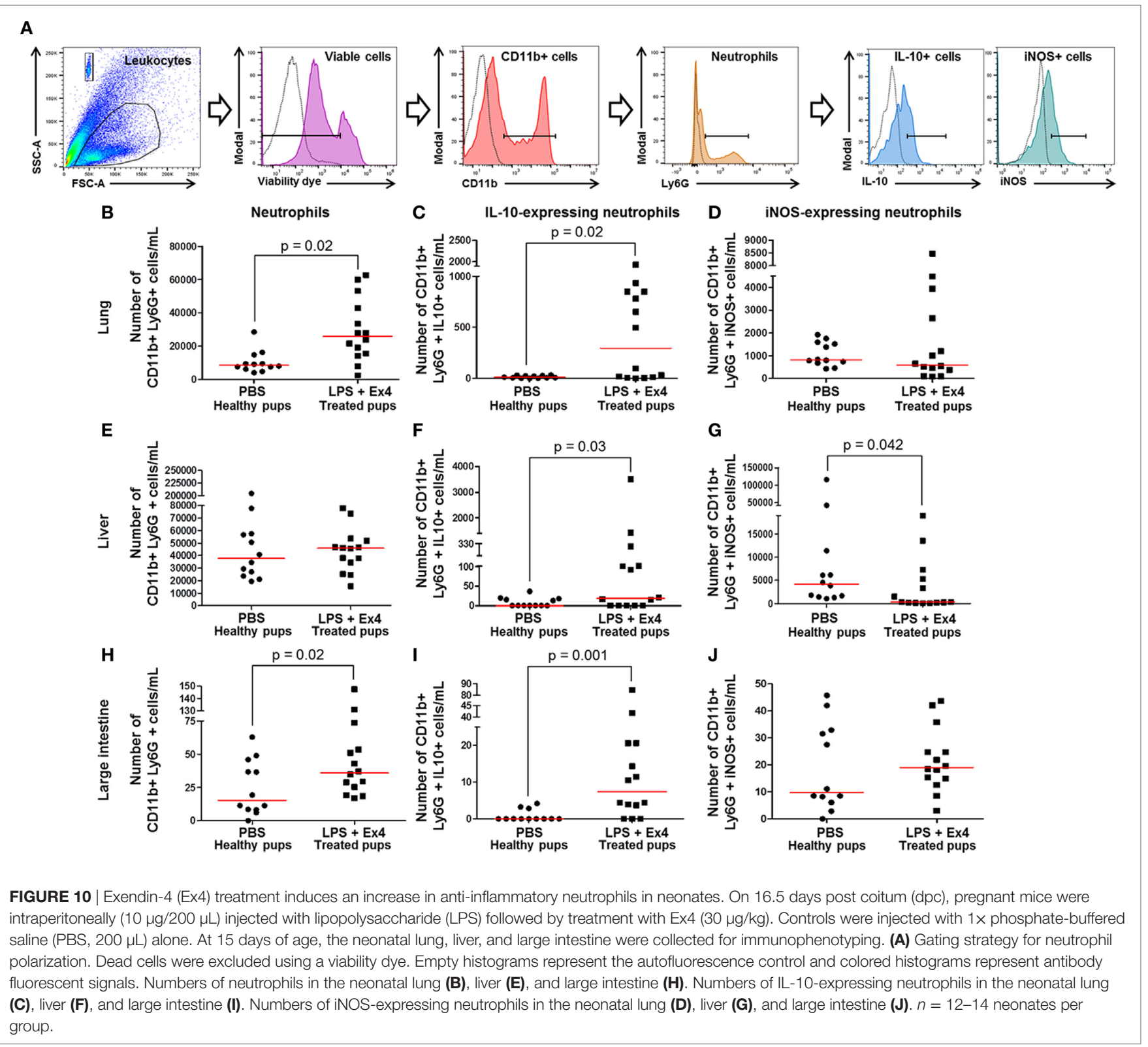

$(112,114)$, including the placenta (113). In addition, the administration of its agonists (Ex4 and liraglutide) increased the expression of surfactant protein A and B in the lung and amniotic fluid, which demonstrates the importance of the GLP-1 system in fetal development $(113,114)$. In the current study, we found that Ex4 was modestly detected in the fetal membranes, suggesting that this peptide could have partial effects on the tissues surrounding the fetus, which translated into thriving neonates.

\section{Innate and Adaptive Immune Responses in Thriving Neonates}

Neonates born to dams with MIR and treated with Ex4 were indistinguishable from healthy control neonates. We, therefore, investigated whether the immune system of these thriving pups was comparable to healthy neonates.
Treatment with Ex4 induced an M2 macrophage polarization in neonates born to dams with systemic inflammation. This is consistent with previous studies demonstrating that glucagonlike peptides, such as Ex4, induce an M2 macrophage polarization in vitro (115) and in vivo (116). M2 macrophages are considered alternatively activated (117-121) and display anti-inflammatory properties through the production of IL-10 and upregulation of arginase-1 (119, 122-128). In addition, decidual M2 macrophages participate in maternal-fetal tolerance throughout pregnancy (55, 129-136), suggesting that Ex4 may also have effects at the maternal-fetal interface. Further studies are required to investigate the effects of GLP-1 analogs in the reproductive tissues and maternal-fetal interface.

Although adult neutrophils are a major component of the innate immune system, neonatal neutrophils tend to have quantitative 

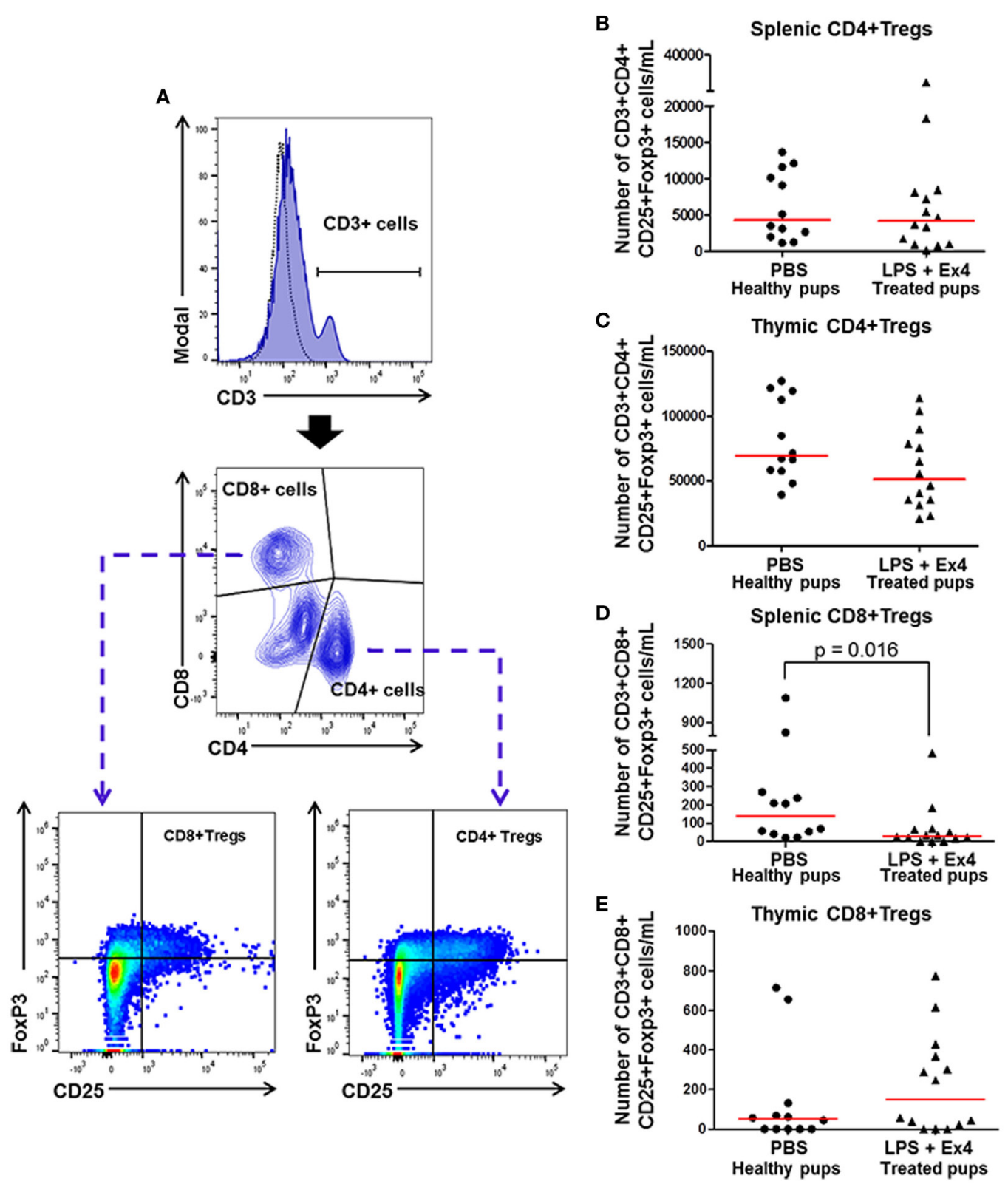

FIGURE 11 | Exendin-4 (Ex4) treatment reduces neonatal CD8+ regulatory T cells (Tregs). On 16.5 days post coitum (dpc), pregnant mice were intraperitoneally $(10 \mu \mathrm{g} / 200 \mu \mathrm{L})$ injected with lipopolysaccharide (LPS) followed by treatment with Ex4 $(30 \mu \mathrm{g} / \mathrm{kg})$. Controls were injected with $1 \times$ phosphate-buffered saline (PBS, $200 \mathrm{LL}$ ) alone. At 15 days of age, the neonatal spleen and thymus were collected for immunophenotyping. (A) Gating strategy for CD4+ and CD8+ T regulatory cells. Dead cells were excluded using a viability dye. Dotted histograms represent the autofluorescence control and colored histograms represent antibody fluorescent signals. CD4+ and CD8+ Tregs co-expressed CD25 and FoxP3. (B,C) Number of splenic and thymic CD4+ Tregs. (D,E) Number of splenic and thymic CD8+ Tregs. $n=12-14$ neonates per group.

and qualitative defects (84). For example, neonatal neutrophils have impaired chemotaxis, rolling adhesion, transmigration, and lamellipodia formation (137). Such innate immune cells also display impairments in anti-microbial mechanisms and are reduced in newborns presenting bacterial sepsis (137). In this study, we found that treatment with Ex4 caused an increase in antiinflammatory neutrophils in neonates born to dams with systemic inflammation. These findings are in line with a previous report demonstrating that Ex4 can modulate neutropenia and dampen pro-inflammatory cytokines (68). Together, these results indicate that Ex4 treatment of dams with systemic inflammation modulates the fetal inflammatory response, which resulted in thriving neonates with increased anti-inflammatory neutrophils.

CD4+ Tregs play a central role in the immune response by preventing autoimmunity (inhibiting self-immune responses) and suppressing defensive immune responses to prevent host 
tissue damage (138-142). In the fetus, CD4+ Tregs are generated during pregnancy to participate in self-tolerance and tolerance to non-inherited antigens on chimeric maternal cells $(85,86)$. CD4+ Tregs are also implicated in the development of neonatal tolerance, where they suppress the development of donor-specific CD8+ $\mathrm{T}$ cell responses $(83,143)$. The fact that neonates born to dams with systemic inflammation and treated with Ex4 had normal numbers of CD4+ Tregs, which were comparable to those of healthy neonates, provides evidence that this peptide does not have deleterious effects on neonatal CD4+ Treg homeostasis.

CD8+ CD25+ $\mathrm{T}$ cells expressing FoxP3 seem to share phenotypic, functional, and mechanistic actions with classical CD4+ Tregs (144-146) and therefore are termed CD8+ Tregs. In neonates, CD8+ Tregs modulate Th2-cell-mediated pathology and autoimmunity $(147,148)$, suggesting that such cells shape the development of the immune system (83). In late pregnancy, however, maternal/decidual CD8+ CD25+ FoxP3+ T cells seem to have pro-inflammatory functions $(90,149)$. Herein, we found that treatment with Ex4 suppressed the expansion of CD8+ Tregs in neonates born to dams with systemic inflammation. The fact that Ex4 reduces CD8+ Tregs in the spleen of neonates born to dams with systemic inflammation suggests that such cells have pro-inflammatory rather than immunosuppressive functions. Yet, a functional assessment of neonatal CD8+ Tregs in the context of infection requires further investigation.

\section{Why Choose Ex4 for the Treatment of Inflammation-Induced Adverse Pregnancy Outcomes?}

Several substances with anti-inflammatory properties have been suggested as possible candidates for the prevention of inflammation-induced adverse pregnancy outcomes; however, further investigation is still required to determine the efficacy and safety of such treatments (41). Herein, we provide data supporting the use of a peptide, Ex4, for the prevention of inflammation-induced preterm labor and birth and adverse neonatal outcomes. Importantly, we found that pregnant dams treated with Ex4 alone did not present adverse pregnancy and neonatal outcomes. Recent reports recognize the use of peptides as highly selective and efficacious therapeutic approaches since these are natural and are therefore relatively safe and well tolerated (59). Indeed, more than 60 peptide drugs have reached the market and approximately 140 peptide therapeutics are currently undergoing evaluation in clinical trials (59). In addition, a case report showed that the administration of Exenatide, the synthetic version of Ex4, to a pregnant woman during the first trimester was not associated with congenital malformation or other adverse pregnancy outcomes (150). Together, these findings suggest that peptides, such as Ex4, are well tolerated and safe for the mother and fetus/neonate. Yet, further research in larger animals is required to evaluate the safety of Ex4.

\section{CONCLUSION}

The findings presented herein provide evidence that Ex4 improves adverse pregnancy and neonatal outcomes by modestly decreasing the rate of preterm birth and drastically improving neonatal survival in a model of maternal systemic inflammation. Moreover, Ex4 treatment of dams with systemic inflammation confers protective effects on the neonates by reducing the expression and systemic concentrations of inflammatory cytokines and promoting an anti-inflammatory phenotype of neonatal immune cells. These resultsprovide evidence that dampening maternal systemicinflammation through novel interventions such as Ex4 can improve the quality of life for neonates born to women with this clinical condition.

\section{ETHICS STATEMENT}

All procedures were approved by the Institutional Animal Care and Use Committee (IACUC) at Wayne State University (Protocol No. A-07-03-15).

\section{AUTHOR CONTRIBUTIONS}

VG-F, DM, YX, BD, CV, YL, MA-H, NK, and NG-L: substantial contributions to the acquisition and/or analysis, and interpretation of data. NG-L and RR: substantial contributions to the conception, design, analysis, and interpretation of data. $\mathrm{BP}, \mathrm{SH}$, and LA-S: substantial contributions to the analysis and interpretation of data. All the authors: drafting the work or revising it critically for important intellectual content; final approval of the version to be submitted for publication; agreement to be accountable for all aspects of the work in ensuring that questions related to the accuracy and integrity of any part of the work are appropriately investigated and resolved.

\section{ACKNOWLEDGMENTS}

We gratefully acknowledge Olesya Plazyo and research assistants of the PRB Translational Laboratory for facilitating the execution of this study. This work was presented in part at the 64th Annual Meeting of the Society for Reproductive Investigation (March 15-18, 2017, Orlando, FL, USA) and the 37th Annual American Society for Reproductive Immunology Meeting (September 17-20, 2017, Chicago, IL, USA).

\section{FUNDING}

This research was supported by the Wayne State University Perinatal Initiative in Maternal, Perinatal and Child Health, Ferring Research Institute Inc. (Ferring Innovation Grant to NG-L), and Perinatology Research Branch (PRB), Division of Intramural Research, Eunice Kennedy Shriver National Institute of Child Health and Human Development, National Institutes of Health, U.S. Department of Health and Human Services (NICHD/ NIH/DHHS). VG-F and MA-H held a doctoral CONACyT scholarship.

\section{SUPPLEMENTARY MATERIAL}

The Supplementary Material for this article can be found online at https://www.frontiersin.org/articles/10.3389/fimmu.2018.01291/ full\#supplementary-material. 


\section{REFERENCES}

1. Romero R, Dey SK, Fisher SJ. Preterm labor: one syndrome, many causes. Science (2014) 345:760-5. doi:10.1126/science.1251816

2. Muglia LJ, Katz M. The enigma of spontaneous preterm birth. N Engl J Med (2010) 362:529-35. doi:10.1056/NEJMra0904308

3. Blencowe H, Cousens S, Oestergaard MZ, Chou D, Moller AB, Narwal R, et al. National, regional, and worldwide estimates of preterm birth rates in the year 2010 with time trends since 1990 for selected countries: a systematic analysis and implications. Lancet (2012) 379:2162-72. doi:10.1016/ S0140-6736(12)60820-4

4. Liu L, Oza S, Hogan D, Perin J, Rudan I, Lawn JE, et al. Global, regional, and national causes of child mortality in 2000-13, with projections to inform post-2015 priorities: an updated systematic analysis. Lancet (2015) 385:430-40. doi:10.1016/S0140-6736(14)61698-6

5. Goldenberg RL, Culhane JF, Iams JD, Romero R. Epidemiology and causes of preterm birth. Lancet (2008) 371:75-84. doi:10.1016/S0140-6736(08) 60074-4

6. Romero R, Lockwood CJ. Pathogenesis of spontaneous preterm labor. 6th ed. In: Creasy RK, Resnik R, Iams JD, editors. Creasy and Resnik's MaternalFetal Medicine: Principles and Practice. Philadelphia, PA: Elsevier (2009). p. 521-43.

7. Yoon BH, Romero R, Moon JB, Shim SS, Kim M, Kim G, et al. Clinical significance of intra-amniotic inflammation in patients with preterm labor and intact membranes. Am J Obstet Gynecol (2001) 185:1130-6. doi:10.1067/ mob.2001.117680

8. Kemp MW. Preterm birth, intrauterine infection, and fetal inflammation. Front Immunol (2014) 5:574. doi:10.3389/fimmu.2014.00574

9. Romero R, Miranda J, Chaiworapongsa T, Korzeniewski SJ, Chaemsaithong P, Gotsch F, et al. Prevalence and clinical significance of sterile intra-amniotic inflammation in patients with preterm labor and intact membranes. Am J Reprod Immunol (2014) 72:458-74. doi:10.1111/aji.12296

10. Kim SM, Romero R, Park JW, Oh KJ, Jun JK, Yoon BH. The relationship between the intensity of intra-amniotic inflammation and the presence and severity of acute histologic chorioamnionitis in preterm gestation. J Matern Fetal Neonatal Med (2015) 28:1500-9. doi:10.3109/14767058.2014.961009

11. Romero R, Miranda J, Chaemsaithong P, Chaiworapongsa T, Kusanovic JP, Dong $\mathrm{Z}$, et al. Sterile and microbial-associated intra-amniotic inflammation in preterm prelabor rupture of membranes. JMatern Fetal Neonatal Med (2015) 28:1394-409. doi:10.3109/14767058.2014.958463

12. Gomez-Lopez N, Romero R, Plazyo O, Panaitescu B, Furcron AE, Miller D, et al. Intra-amniotic administration of HMGB1 induces spontaneous preterm labor and birth. Am J Reprod Immunol (2016) 75:3-7. doi:10.1111/ aji. 12443

13. Plazyo O, Romero R, Unkel R, Balancio A, Mial TN, Xu Y, et al. HMGB1 induces an inflammatory response in the chorioamniotic membranes that is partially mediated by the inflammasome. Biol Reprod (2016) 95:130. doi:10.1095/biolreprod.116.144139

14. Anders AP, GaddyJA, Doster RS, AronoffDM. Current concepts in maternalfetal immunology: recognition and response to microbial pathogens by decidual stromal cells. Am J Reprod Immunol (2017) 77:e12623. doi:10.1111/aji.12623

15. Gibbs RS, Blanco JD, St Clair PJ, Castaneda YS. Quantitative bacteriology of amniotic fluid from women with clinical intraamniotic infection at term. J Infect Dis (1982) 145:1-8. doi:10.1093/infdis/145.1.1

16. Gibbs RS, Dinsmoor MJ, Newton ER, Ramamurthy RS. A randomized trial of intrapartum versus immediate postpartum treatment of women with intra-amniotic infection. Obstet Gynecol (1988) 72:823-8. doi:10.1097/00006250-198812000-00001

17. Gibbs RS, Duff P. Progress in pathogenesis and management of clinical intraamniotic infection. Am J Obstet Gynecol (1991) 164:1317-26. doi:10.1016/ 0002-9378(91)90707-X

18. Romero R, Chaemsaithong P, Docheva N, Korzeniewski SJ, Tarca AL, Bhatti G, et al. Clinical chorioamnionitis at term IV: the maternal plasma cytokine profile. J Perinat Med (2016) 44:77-98. doi:10.1515/jpm-20150103

19. Romero R, Quintero R, Nores J, Avila C, Mazor M, Hanaoka S, et al. Amniotic fluid white blood cell count: a rapid and simple test to diagnose microbial invasion of the amniotic cavity and predict preterm delivery. Am J Obstet Gynecol (1991) 165:821-30. doi:10.1016/0002-9378(91)90423-O

20. Gomez R, Romero R, Galasso M, Behnke E, Insunza A, Cotton DB. The value of amniotic fluid interleukin-6, white blood cell count, and Gram stain in the diagnosis of microbial invasion of the amniotic cavity in patients at term. Am J Reprod Immunol (1994) 32:200-10. doi:10.1111/j.1600-0897.1994. tb01115.x

21. Yoon BH, Yang SH, Jun JK, Park KH, Kim CJ, Romero R. Maternal blood C-reactive protein, white blood cell count, and temperature in preterm labor: a comparison with amniotic fluid white blood cell count. Obstet Gynecol (1996) 87:231-7. doi:10.1016/0029-7844(95)00380-0

22. Martinez-Varea A, Romero R, Xu Y, Miller D, Ahmed AI, Chaemsaithong P, et al. Clinical chorioamnionitis at term VII: the amniotic fluid cellular immune response. J Perinat Med (2017) 45:523-38. doi:10.1515/jpm-20160225

23. Romero R, Grivel JC, Tarca AL, Chaemsaithong P, Xu Z, Fitzgerald W, et al. Evidence of perturbations of the cytokine network in preterm labor. Am J Obstet Gynecol (2015) 213:836.e1-836.e18. doi:10.1016/j.ajog.2015. 07.037

24. Romero R, Emamian M, Quintero R, Wan M, Hobbins JC, Mitchell MD. Amniotic fluid prostaglandin levels and intra-amniotic infections. Lancet (1986) 1:1380. doi:10.1016/S0140-6736(86)91685-5

25. Bry K, Hallman M. Prostaglandins, inflammation, and preterm labor. J Perinatol (1989) 9:60-5.

26. Mazor M, Wiznitzer A, Maymon E, Leiberman JR, Cohen A. Changes in amniotic fluid concentrations of prostaglandins E2 and F2 alpha in women with preterm labor. Isr J Med Sci (1990) 26:425-8.

27. Hsu CD, Meaddough E, Aversa K, Hong SF, Lee IS, Bahodo-Singh RO, et al. Dual roles of amniotic fluid nitric oxide and prostaglandin E2 in preterm labor with intra-amniotic infection. Am J Perinatol (1998) 15:683-7. doi:10.1055/s-2007-999302

28. Lee SE, Park IS, Romero R, Yoon BH. Amniotic fluid prostaglandin F2 increases even in sterile amniotic fluid and is an independent predictor of impending delivery in preterm premature rupture of membranes. J Matern Fetal Neonatal Med (2009) 22:880-6. doi:10.1080/1476705090 2994648

29. Maddipati KR, Romero R, Chaiworapongsa T, Zhou SL, Xu Z, Tarca AL, et al. Eicosanomic profiling reveals dominance of the epoxygenase pathway in human amniotic fluid at term in spontaneous labor. FASEB J (2014) 28:4835-46. doi:10.1096/fj.14-254383

30. Maddipati KR, Romero R, Chaiworapongsa T, Chaemsaithong P, Zhou SL, $\mathrm{Xu} \mathrm{Z}$, et al. Lipidomic analysis of patients with microbial invasion of the amniotic cavity reveals up-regulation of leukotriene B4. FASEB J (2016) 30:3296-307. doi:10.1096/fj.201600583R

31. Park JY, Romero R, Lee J, Chaemsaithong P, Chaiyasit N, Yoon BH. An elevated amniotic fluid prostaglandin F2alpha concentration is associated with intra-amniotic inflammation/infection, and clinical and histologic chorioamnionitis, as well as impending preterm delivery in patients with preterm labor and intact membranes. J Matern Fetal Neonatal Med (2016) 29:2563-72. doi:10.3109/14767058.2015.1094794

32. Gomez R, Romero R, Ghezzi F, Yoon BH, Mazor M, Berry SM. The fetal inflammatory response syndrome. Am J Obstet Gynecol (1998) 179:194-202. doi:10.1016/S0002-9378(98)70272-8

33. Gotsch F, Romero R, Kusanovic JP, Mazaki-Tovi S, Pineles BL, Erez O, et al. The fetal inflammatory response syndrome. Clin Obstet Gynecol (2007) 50:652-83. doi:10.1097/GRF.0b013e31811ebef6

34. Romero R, Gomez R, Ghezzi F, Yoon BH, Mazor M, Edwin SS, et al. A fetal systemic inflammatory response is followed by the spontaneous onset of preterm parturition. Am J Obstet Gynecol (1998) 179:186-93. doi:10.1016/ S0002-9378(98)70271-6

35. Pacora P, Chaiworapongsa T, Maymon E, Kim YM, Gomez R, Yoon BH, et al. Funisitis and chorionic vasculitis: the histological counterpart of the fetal inflammatory response syndrome. J Matern Fetal Neonatal Med (2002) 11:18-25. doi:10.1080/jmf.11.1.18.25

36. Kim CJ, Romero R, Chaemsaithong P, Chaiyasit N, Yoon BH, Kim YM. Acute chorioamnionitis and funisitis: definition, pathologic features, and clinical significance. Am J Obstet Gynecol (2015) 213:S29-52. doi:10.1016/j. ajog.2015.08.040 
37. Redline RW. Classification of placental lesions. Am J Obstet Gynecol (2015) 213:S21-8. doi:10.1016/j.ajog.2015.05.056

38. Panaitescu B, Romero R, Gomez-Lopez N, Yeo L, Gotsch F. Intrauterine infection, preterm parturition, and the fetal inflammatory response syndrome. 5th ed. In: James D, Steer PJ, Weiner CP, Gonik B, Robson SC, editors. High-Risk Pregnancy: Management Options. Cambridge, UK: Cambridge University Press (2018). p. 579-603.

39. Lamont RF. Advances in the prevention of infection-related preterm birth. Front Immunol (2015) 6:566. doi:10.3389/fimmu.2015.00566

40. Keelan JA, Payne MS, Kemp MW, Ireland DJ, Newnham JP. A new, potent, and placenta-permeable macrolide antibiotic, solithromycin, for the prevention and treatment of bacterial infections in pregnancy. Front Immunol (2016) 7:111. doi:10.3389/fimmu.2016.00111

41. Taguchi A, Yamashita A, Kawana K, Nagamatsu T, Furuya H, Inoue E, et al. Recent progress in therapeutics for inflammation-associated preterm birth: a review. Reprod Sci (2015) 24:7-18. doi:10.1177/1933719115618282

42. Holmgren C, Esplin MS, Hamblin S, Molenda M, Simonsen S, Silver R. Evaluation of the use of anti-TNF-alpha in an LPS-induced murine model. J Reprod Immunol (2008) 78:134-9. doi:10.1016/j.jri.2007.11.003

43. Wakabayashi A, Sawada K, Nakayama M, Toda A, Kimoto A, Mabuchi S, et al. Targeting interleukin-6 receptor inhibits preterm delivery induced by inflammation. Mol Hum Reprod (2013) 19:718-26. doi:10.1093/molehr/ gat057

44. Leitner K, Al Shammary M, Mclane M, Johnston MV, Elovitz MA, Burd I. IL-1 receptor blockade prevents fetal cortical brain injury but not preterm birth in a mouse model of inflammation-induced preterm birth and perinatal brain injury. Am J Reprod Immunol (2014) 71:418-26. doi:10.1111/ aji. 12216

45. Nadeau-Vallee M, Quiniou C, Palacios J, Hou X, Erfani A, Madaan A, et al. Novel noncompetitive IL-1 receptor-biased ligand prevents infection- and inflammation-induced preterm birth. J Immunol (2015) 195:3402-15. doi:10.4049/jimmunol.1500758

46. Shynlova O, Dorogin A, Li Y, Lye S. Inhibition of infection-mediated preterm birth by administration of broad spectrum chemokine inhibitor in mice. J Cell Mol Med (2014) 18:1816-29. doi:10.1111/jcmm.12307

47. Sakai M, Tanebe K, Sasaki Y, Momma K, Yoneda S, Saito S. Evaluation of the tocolytic effect of a selective cyclooxygenase-2 inhibitor in a mouse model of lipopolysaccharide-induced preterm delivery. Mol Hum Reprod (2001) 7:595-602. doi:10.1093/molehr/7.6.595

48. Elovitz M, Wang Z. Medroxyprogesterone acetate, but not progesterone, protects against inflammation-induced parturition and intrauterine fetal demise. Am J Obstet Gynecol (2004) 190:693-701. doi:10.1016/j.ajog.2003. 10.693

49. Furcron AE, Romero R, Plazyo O, Unkel R, Xu Y, Hassan SS, et al. Vaginal progesterone, but not 17alpha-hydroxyprogesterone caproate, has antiinflammatory effects at the murine maternal-fetal interface. Am J Obstet Gynecol (2015) 213:846.e841-846.e819. doi:10.1016/j.ajog.2015. 08.010

50. Furcron AE, Romero R, Mial TN, Balancio A, Panaitescu B, Hassan SS, et al. Human chorionic gonadotropin has anti-inflammatory effects at the maternal-fetal interface and prevents endotoxin-induced preterm birth, but causes dystocia and fetal compromise in mice. Biol Reprod (2016) 94:136. doi:10.1095/biolreprod.116.139345

51. Furuya H, Taguchi A, Kawana K, Yamashita A, Inoue E, Yoshida M, et al. Resveratrol protects against pathological preterm birth by suppression of macrophage-mediated inflammation. Reprod Sci (2015) 22:1561-8. doi:10.1177/1933719115589413

52. Yamashita A, Kawana $\mathrm{K}$, Tomio $\mathrm{K}$, Taguchi A, Isobe $\mathrm{Y}$, Iwamoto $\mathrm{R}$, et al. Increased tissue levels of omega-3 polyunsaturated fatty acids prevents pathological preterm birth. Sci Rep (2013) 3:3113. doi:10.1038/ srep03113

53. Pirianov G, Waddington SN, Lindstrom TM, Terzidou V, Mehmet H, Bennett PR. The cyclopentenone 15-deoxy-delta 12,14-prostaglandin J(2) delays lipopolysaccharide-induced preterm delivery and reduces mortality in the newborn mouse. Endocrinology (2009) 150:699-706. doi:10.1210/en. 2008-1178

54. St Louis D, Romero R, Plazyo O, Arenas-Hernandez M, Panaitescu B, Xu Y, et al. Invariant NKT cell activation induces late preterm birth that is attenuated by rosiglitazone. J Immunol (2016) 196:1044-59. doi:10.4049/ jimmunol.1501962

55. Xu Y, Romero R, Miller D, Kadam L, Mial TN, Plazyo O, et al. An M1-like macrophage polarization in decidual tissue during spontaneous preterm labor that is attenuated by rosiglitazone treatment. JImmunol (2016) 196:2476-91. doi:10.4049/jimmunol.1502055

56. Gomez-Lopez N, Romero R, Arenas-Hernandez M, Schwenkel G, St Louis D, Hassan SS, et al. In vivo activation of invariant natural killer T cells induces systemic and local alterations in T-cell subsets prior to preterm birth. Clin Exp Immunol (2017) 189:211-25. doi:10.1111/cei.12968

57. Basraon SK, Menon R, Makhlouf M, Longo M, Hankins GD, Saade GR, et al. Can statins reduce the inflammatory response associated with preterm birth in an animal model? Am J Obstet Gynecol (2012) 207:224.e221-227. doi:10.1016/j.ajog.2012.06.020

58. Yang S, Li W, Challis JR, Reid G, Kim SO, Bocking AD. Probiotic Lactobacillus rhamnosus GR-1 supernatant prevents lipopolysaccharide-induced preterm birth and reduces inflammation in pregnant CD-1 mice. Am J Obstet Gynecol (2014) 211:44.e41-44.e12. doi:10.1016/j.ajog.2014.01.029

59. Fosgerau K, Hoffmann T. Peptide therapeutics: current status and future directions. Drug Discov Today (2015) 20:122-8. doi:10.1016/j.drudis.2014. 10.003

60. Davidson MB, Bate G, Kirkpatrick P. Exenatide. Nat Rev Drug Discov (2005) 4:713-4. doi:10.1038/nrd 1828

61. Drucker DJ, Philippe J, Mojsov S, Chick WL, Habener JF. Glucagon-like peptide I stimulates insulin gene expression and increases cyclic AMP levels in a rat islet cell line. Proc Natl Acad Sci U S A (1987) 84:3434-8. doi:10.1073/ pnas.84.10.3434

62. Korner M, Stockli M, Waser B, Reubi JC. GLP-1 receptor expression in human tumors and human normal tissues: potential for in vivo targeting. J Nucl Med (2007) 48:736-43. doi:10.2967/jnumed.106.038679

63. Carlessi R, Lemos NE, Dias AL, Brondani LA, Oliveira JR, Bauer AC, et al. Exendin- 4 attenuates brain death-induced liver damage in the rat. Liver Transpl (2015) 21:1410-8. doi:10.1002/lt.24317

64. Wang Y, Parlevliet ET, Geerling JJ, Van Der Tuin SJ, Zhang H, Bieghs V, et al. Exendin- 4 decreases liver inflammation and atherosclerosis development simultaneously by reducing macrophage infiltration. Br J Pharmacol (2014) 171:723-34. doi:10.1111/bph.12490

65. Kodera R, Shikata K, Kataoka HU, Takatsuka T, Miyamoto S, Sasaki M, et al. Glucagon-like peptide-1 receptor agonist ameliorates renal injury through its anti-inflammatory action without lowering blood glucose level in a rat model of type 1 diabetes. Diabetologia (2011) 54:965-78. doi:10.1007/ s00125-010-2028-x

66. Robinson E, Cassidy RS, Tate M, Zhao Y, Lockhart S, Calderwood D, et al. Exendin-4 protects against post-myocardial infarction remodelling via specific actions on inflammation and the extracellular matrix. Basic Res Cardiol (2015) 110:20. doi:10.1007/s00395-015-0476-7

67. Guo C, Huang T, Chen A, Chen X, Wang L, Shen F, et al. Glucagon-like peptide 1 improves insulin resistance in vitro through anti-inflammation of macrophages. Braz J Med Biol Res (2016) 49:e5826. doi:10.1590/ 1414-431X20165826

68. Yanay O, Bailey AL, Kernan K, Zimmerman JJ, Osborne WR. Effects of exendin-4, a glucagon like peptide-1 receptor agonist, on neutrophil count and inflammatory cytokines in a rat model of endotoxemia. J Inflamm Res (2015) 8:129-35. doi:10.2147/JIR.S84993

69. Buldak L, Machnik G, Buldak RJ, Labuzek K, Boldys A, Belowski D, et al. Exenatide (a GLP-1 agonist) expresses anti-inflammatory properties in cultured human monocytes/macrophages in a protein kinase A and B/ Akt manner. Pharmacol Rep (2016) 68:329-37. doi:10.1016/j.pharep.2015. 10.008

70. Buldak L, Machnik G, Buldak RJ, Labuzek K, Boldys A, Okopien B. Exenatide and metformin express their anti-inflammatory effects on human monocytes/macrophages by the attenuation of MAPKs and NFkappaB signaling. Naunyn Schmiedebergs Arch Pharmacol (2016) 389:1103-15. doi:10.1007/ s00210-016-1277-8

71. He L, Wong CK, Cheung KK, Yau HC, Fu A, Zhao HL, et al. Anti-inflammatory effects of exendin-4, a glucagon-like peptide- 1 analog, on human peripheral lymphocytes in patients with type 2 diabetes. J Diabetes Investig (2013) 4: 382-92. doi:10.1111/jdi.12063 
72. He L, Law PTY, Wong CK, Chan JCN, Chan PKS. Exendin-4 exhibits enhanced anti-tumor effects in diabetic mice. Sci Rep (2017) 7:1791. doi:10.1038/s41598-017-01952-5

73. Gomez-Lopez N, Romero R, Arenas-Hernandez M, Panaitescu B, GarciaFlores V, Mial TN, et al. Intra-amniotic administration of lipopolysaccharide induces spontaneous preterm labor and birth in the absence of a body temperature change. J Matern Fetal Neonatal Med (2017) 31(4):439-46. doi:10.1080/14767058.2017.1287894

74. Arenas-Hernandez M, Sanchez-Rodriguez EN, Mial TN, Robertson SA, Gomez-Lopez N. Isolation of leukocytes from the murine tissues at the maternal-fetal interface. J Vis $\operatorname{Exp}$ (2015) 21:e52866. doi:10.3791/52866

75. Kallapur SG, Willet KE, Jobe AH, Ikegami M, Bachurski CJ. Intra-amniotic endotoxin: chorioamnionitis precedes lung maturation in preterm lambs. Am J Physiol Lung Cell Mol Physiol (2001) 280:L527-36. doi:10.1152/ajplung. 2001.280.3.L527

76. Kramer BW, Moss TJ, Willet KE, Newnham JP, Sly PD, Kallapur SG, et al. Dose and time response after intraamniotic endotoxin in preterm lambs. Am J Respir Crit Care Med (2001) 164:982-8. doi:10.1164/ajrccm.164.6. 2103061

77. Ozalkaya E, Karatekin G, Topcuoglu S, Gursoy T, Ovali F. Morbidity in preterm infants with fetal inflammatory response syndrome. Pediatr Int (2016) 58:850-4. doi:10.1111/ped.12895

78. Yoon BH, Romero R, Jun JK, Park KH, Park JD, Ghezzi F, et al. Amniotic fluid cytokines (interleukin-6, tumor necrosis factor-alpha, interleukin-1 beta, and interleukin-8) and the risk for the development of bronchopulmonary dysplasia. Am J Obstet Gynecol (1997) 177:825-30. doi:10.1016/S0002-9378 (97)70276-X

79. Ghezzi F, Gomez R, Romero R, Yoon BH, Edwin SS, David C, et al. Elevated interleukin-8 concentrations in amniotic fluid of mothers whose neonates subsequently develop bronchopulmonary dysplasia. Eur J Obstet Gynecol Reprod Biol (1998) 78:5-10. doi:10.1016/S0301-2115(97)00236-4

80. Yoon BH, Romero R, Kim KS, Park JS, Ki SH, Kim BI, et al. A systemic fetal inflammatory response and the development of bronchopulmonary dysplasia. Am J Obstet Gynecol (1999) 181:773-9. doi:10.1016/S0002-9378(99) 70299-1

81. Yoon BH, Romero R, Shim J, Lim J, Cho E, Jung H, et al. "Atypical” chronic lung disease of the newborn is linked to fetal systemic inflammation. Am J Obstet Gynecol (2002) 187:S129.

82. Chicchi GG, Cascieri MA, Graziano MP, Calahan T, Tota MR. FluoresceinTrp25-exendin-4, a biologically active fluorescent probe for the human GLP-1 receptor. Peptides (1997) 18:319-21. doi:10.1016/S0196-9781(96) 00320-8

83. Adkins B, Leclerc C, Marshall-Clarke S. Neonatal adaptive immunity comes of age. Nat Rev Immunol (2004) 4:553-64. doi:10.1038/nri1394

84. Basha S, Surendran N, Pichichero M. Immune responses in neonates. Expert Rev Clin Immunol (2014) 10:1171-84. doi:10.1586/1744666X.2014.942288

85. Mold JE, Michaelsson J, Burt TD, Muench MO, Beckerman KP, Busch MP, et al. Maternal alloantigens promote the development of tolerogenic fetal regulatory T cells in utero. Science (2008) 322:1562-5. doi:10.1126/science. 1164511

86. Burt TD. Fetal regulatory $\mathrm{T}$ cells and peripheral immune tolerance in utero: implications for development and disease. Am J Reprod Immunol (2013) 69:346-58. doi:10.1111/aji.12083

87. Kallapur SG, Presicce P, Senthamaraikannan P, Alvarez M, Tarantal AF, Miller LM, et al. Intra-amniotic IL-1beta induces fetal inflammation in rhesus monkeys and alters the regulatory T cell/IL-17 balance. J Immunol (2013) 191:1102-9. doi:10.4049/jimmunol.1300270

88. Rueda CM, Wells CB, Gisslen T, Jobe AH, Kallapur SG, Chougnet CA. Effect of chorioamnionitis on regulatory $\mathrm{T}$ cells in moderate/late preterm neonates. Hum Immunol (2015) 76:65-73. doi:10.1016/j.humimm.2014.10.016

89. Pan H, Gazarian A, Dubernard JM, Belot A, Michallet MC, Michallet M. Transplant tolerance induction in newborn infants: mechanisms, advantages, and potential strategies. Front Immunol (2016) 7:116. doi:10.3389/ fimmu.2016.00116

90. Gomez-Lopez N, Olson DM, Robertson SA. Interleukin-6 controls uterine Th9 cells and CD8(+) T regulatory cells to accelerate parturition in mice. Immunol Cell Biol (2016) 94:79-89. doi:10.1038/icb.2015.63

91. Romero R, Roslansky P, Oyarzun E, Wan M, Emamian M, Novitsky TJ, et al. Labor and infection. II. Bacterial endotoxin in amniotic fluid and its relationship to the onset of preterm labor. Am J Obstet Gynecol (1988) 158:1044-9. doi:10.1016/0002-9378(88)90216-5

92. Goodlin RC, Brooks PG. Abdominal wall hot spots in pregnant women. J Reprod Med (1987) 32:177-80.

93. Sheinberg M, Hayashi R, Bromley J, Dormer L. Application of telethermography in the evaluation of preterm premature rupture of the fetal membranes. Biomed Instrum Technol (1996) 30:526-30.

94. Romero R, Sirtori M, Oyarzun E, Avila C, Mazor M, Callahan R, et al. Infection and labor. V. Prevalence, microbiology, and clinical significance of intraamniotic infection in women with preterm labor and intact membranes. Am J Obstet Gynecol (1989) 161:817-24. doi:10.1016/0002-9378(89) 90409-2

95. Romero R, Miranda J, Chaiworapongsa T, Chaemsaithong P, Gotsch F, Dong Z, et al. A novel molecular microbiologic technique for the rapid diagnosis of microbial invasion of the amniotic cavity and intra-amniotic infection in preterm labor with intact membranes. Am J Reprod Immunol (2014) 71: 330-58. doi:10.1111/aji.12189

96. Romero R, Miranda J, Kusanovic JP, Chaiworapongsa T, Chaemsaithong P, Martinez A, et al. Clinical chorioamnionitis at term I: microbiology of the amniotic cavity using cultivation and molecular techniques. J Perinat Med (2015) 43:19-36. doi:10.1515/jpm-2014-0249

97. Yoneda N, Yoneda S, Niimi H, Ueno T, Hayashi S, Ito M, et al. Polymicrobial amniotic fluid infection with mycoplasma/ureaplasma and other bacteria induces severe intra-amniotic inflammation associated with poor perinatal prognosis in preterm labor. Am J Reprod Immunol (2016) 75:112-25. doi:10.1111/aji.12456

98. Gilstrap LC III, Cox SM. Acute chorioamnionitis. Obstet Gynecol Clin North Am (1989) 16:373-9.

99. Romero R, Chaiworapongsa T, Espinoza J. Micronutrients and intrauterine infection, preterm birth and the fetal inflammatory response syndrome. J Nutr (2003) 133:1668S-73S. doi:10.1093/jn/133.5.1668S

100. Lee SE, Romero R, Kim CJ, Shim SS, Yoon BH. Funisitis in term pregnancy is associated with microbial invasion of the amniotic cavity and intra-amniotic inflammation. J Matern Fetal Neonatal Med (2006) 19:693-7. doi:10.1080/14767050600927353

101. Lee SE, Romero R, Jung H, Park CW, Park JS, Yoon BH. The intensity of the fetal inflammatory response in intraamniotic inflammation with and without microbial invasion of the amniotic cavity. Am J Obstet Gynecol (2007) 197(294):e291-6. doi:10.1016/j.ajog.2007.07.006

102. Romero R, Chaemsaithong P, Docheva N, Korzeniewski SJ, Tarca AL, Bhatti G, et al. Clinical chorioamnionitis at term V: umbilical cord plasma cytokine profile in the context of a systemic maternal inflammatory response. J Perinat Med (2016) 44:53-76. doi:10.1515/jpm-2015-0121

103. Son GH, You YA, Kwon EJ, Lee KY, Kim YJ. Comparative analysis of midtrimester amniotic fluid cytokine levels to predict spontaneous very pre-term birth in patients with cervical insufficiency. Am J Reprod Immunol (2016) 75:155-61. doi:10.1111/aji.12451

104. Gotsch F, Romero R, Espinoza J, Kusanovic JP, Mazaki-Tovi S, Erez O, et al. Maternal serum concentrations of the chemokine CXCL10/IP-10 are elevated in acute pyelonephritis during pregnancy. J Matern Fetal Neonatal Med (2007) 20:735-44. doi:10.1080/14767050701511650

105. Madan I, Than NG, Romero R, Chaemsaithong P, Miranda J, Tarca AL, et al. The peripheral whole-blood transcriptome of acute pyelonephritis in human pregnancy. J Perinat Med (2014) 42:31-53. doi:10.1515/jpm2013-0085

106. Tita AT, Andrews WW. Diagnosis and management of clinical chorioamnionitis. Clin Perinatol (2010) 37:339-54. doi:10.1016/j.clp.2010.02.003

107. Farkash E, Weintraub AY, Sergienko R, Wiznitzer A, Zlotnik A, Sheiner E. Acute antepartum pyelonephritis in pregnancy: a critical analysis of risk factors and outcomes. Eur J Obstet Gynecol Reprod Biol (2012) 162:24-7. doi:10.1016/j.ejogrb.2012.01.024

108. Martinelli P, Sarno L, Maruotti GM, Paludetto R. Chorioamnionitis and prematurity: a critical review. J Matern Fetal Neonatal Med (2012) 25(Suppl 4):29-31. doi:10.3109/14767058.2012.714981

109. Oh KJ, Kim SM, Hong JS, Maymon E, Erez O, Panaitescu B, et al. Twenty-four percent of patients with clinical chorioamnionitis in preterm gestations have no evidence of either culture-proven intraamniotic infection or intraamniotic inflammation. Am J Obstet Gynecol (2017) 216:604.e1-11. doi:10.1016/j. ajog.2017.02.035 
110. Dulay AT, Buhimschi IA, Zhao G, Bahtiyar MO, Thung SF, Cackovic M, et al. Compartmentalization of acute phase reactants interleukin-6, C-reactive protein and procalcitonin as biomarkers of intra-amniotic infection and chorioamnionitis. Cytokine (2015) 76:236-43. doi:10.1016/j.cyto.2015. 04.014

111. Steven S, Hausding M, Kroller-Schon S, Mader M, Mikhed Y, Stamm P, et al. Gliptin and GLP-1 analog treatment improves survival and vascular inflammation/dysfunction in animals with lipopolysaccharide-induced endotoxemia. Basic Res Cardiol (2015) 110:6. doi:10.1007/s00395-0150465-x

112. Campos RV, Lee YC, Drucker DJ. Divergent tissue-specific and developmental expression of receptors for glucagon and glucagon-like peptide-1 in the mouse. Endocrinology (1994) 134:2156-64. doi:10.1210/endo.134.5. 8156917

113. Ouhilal S, Vuguin P, Cui L, Du XQ, Gelling RW, Reznik SE, et al. Hypoglycemia, hyperglucagonemia, and fetoplacental defects in glucagon receptor knockout mice: a role for glucagon action in pregnancy maintenance. Am J Physiol Endocrinol Metab (2012) 302:E522-31. doi:10.1152/ajpendo. 00420.2011

114. Romani-Perez M, Outeirino-Iglesias V, Gil-Lozano M, Gonzalez-Matias LC, Mallo F, Vigo E. Pulmonary GLP-1 receptor increases at birth and exogenous GLP-1 receptor agonists augmented surfactant-protein levels in litters from normal and nitrofen-treated pregnant rats. Endocrinology (2013) 154: 1144-55. doi:10.1210/en.2012-1786

115. Shiraishi D, Fujiwara Y, Komohara Y, Mizuta H, Takeya M. Glucagonlike peptide-1 (GLP-1) induces M2 polarization of human macrophages via STAT3 activation. Biochem Biophys Res Commun (2012) 425:304-8. doi:10.1016/j.bbrc.2012.07.086

116. Darsalia V, Hua S, Larsson M, Mallard C, Nathanson D, Nystrom T, et al. Exendin-4 reduces ischemic brain injury in normal and aged type 2 diabetic mice and promotes microglial M2 polarization. PLoS One (2014) 9:e103114. doi:10.1371/journal.pone.0103114

117. Stein M, Keshav S, Harris N, Gordon S. Interleukin 4 potently enhances murine macrophage mannose receptor activity: a marker of alternative immunologic macrophage activation. J Exp Med (1992) 176:287-92. doi:10.1084/ jem.176.1.287

118. Doyle AG, Herbein G, Montaner LJ, Minty AJ, Caput D, Ferrara P, et al. Interleukin-13 alters the activation state of murine macrophages in vitro: comparison with interleukin-4 and interferon-gamma. Eur J Immunol (1994) 24:1441-5. doi:10.1002/eji.1830240630

119. Mills CD, Kincaid K, Alt JM, Heilman MJ, Hill AM. M-1/M-2 macrophages and the Th1/Th2 paradigm. J Immunol (2000) 164:6166-73. doi:10.4049/ jimmunol.164.12.6166

120. Anderson CF, Mosser DM. A novel phenotype for an activated macrophage: the type 2 activated macrophage. J Leukoc Biol (2002) 72:101-6.

121. Braga TT, Agudelo JS, Camara NO. Macrophages during the fibrotic process: M2 as friend and foe. Front Immunol (2015) 6:602. doi:10.3389/ fimmu.2015.00602

122. Mosser DM. The many faces of macrophage activation. J Leukoc Biol (2003) 73:209-12. doi:10.1189/jlb.0602325

123. Mantovani A, Sica A, Sozzani S, Allavena P, Vecchi A, Locati M. The chemokine system in diverse forms of macrophage activation and polarization. Trends Immunol (2004) 25:677-86. doi:10.1016/j.it.2004.09.015

124. Verreck FA, De Boer T, Langenberg DM, Hoeve MA, Kramer M, Vaisberg E, et al. Human IL-23-producing type 1 macrophages promote but IL-10-producing type 2 macrophages subvert immunity to (myco)bacteria. Proc Natl Acad Sci U S A (2004) 101:4560-5. doi:10.1073/pnas.0400 983101

125. Pesce JT, Ramalingam TR, Mentink-Kane MM, Wilson MS, El Kasmi KC, Smith AM, et al. Arginase-1-expressing macrophages suppress Th2 cytokine-driven inflammation and fibrosis. PLoS Pathog (2009) 5:e1000371. doi:10.1371/journal.ppat.1000371

126. Biswas SK, Mantovani A. Macrophage plasticity and interaction with lymphocyte subsets: cancer as a paradigm. Nat Immunol (2010) 11:889-96. doi:10.1038/ni.1937

127. Biswas SK, Mantovani A. Orchestration of metabolism by macrophages. Cell Metab (2012) 15:432-7. doi:10.1016/j.cmet.2011.11.013
128. Braga TT, Moura IC, Lepique AP, Camara NOS. Editorial: macrophages role in integrating tissue signals and biological processes in chronic inflammation and fibrosis. Front Immunol (2017) 8:845. doi:10.3389/fimmu.2017.00845

129. Gustafsson C, Mjosberg J, Matussek A, Geffers R, Matthiesen L, Berg G, et al. Gene expression profiling of human decidual macrophages: evidence for immunosuppressive phenotype. PLoS One (2008) 3:e2078. doi:10.1371/ journal.pone.0002078

130. Svensson J, Jenmalm MC, Matussek A, Geffers R, Berg G, Ernerudh J. Macrophages at the fetal-maternal interface express markers of alternative activation and are induced by M-CSF and IL-10. J Immunol (2011) 187: 3671-82. doi:10.4049/jimmunol.1100130

131. Kim SY, Romero R, Tarca AL, Bhatti G, Kim CJ, Lee J, et al. Methylome of fetal and maternal monocytes and macrophages at the feto-maternal interface. $\mathrm{Am}$ J Reprod Immunol (2012) 68:8-27. doi:10.1111/j.1600-0897.2012.01108.x

132. Gomez-Lopez N, Stlouis D, Lehr MA, Sanchez-Rodriguez EN, ArenasHernandez M. Immune cells in term and preterm labor. Cell Mol Immunol (2014) 11:571-81. doi:10.1038/cmi.2014.46

133. Kwan M, Hazan A, Zhang J, Jones RL, Harris LK, Whittle W, et al. Dynamic changes in maternal decidual leukocyte populations from first to second trimester gestation. Placenta (2014) 35:1027-34. doi:10.1016/j. placenta.2014.09.018

134. Svensson-Arvelund J, Ernerudh J. The role of macrophages in promoting and maintaining homeostasis at the fetal-maternal interface. Am J Reprod Immunol (2015) 74:100-9. doi:10.1111/aji.12357

135. Svensson-Arvelund J, Mehta RB, Lindau R, Mirrasekhian E, RodriguezMartinez H, Berg G, et al. The human fetal placenta promotes tolerance against the semiallogeneic fetus by inducing regulatory $\mathrm{T}$ cells and homeostatic M2 macrophages. J Immunol (2015) 194:1534-44. doi:10.4049/jimmunol. 1401536

136. Zhang YH, He M, Wang Y, Liao AH. Modulators of the balance between M1 and M2 macrophages during pregnancy. Front Immunol (2017) 8:120. doi:10.3389/fimmu.2017.00120

137. Levy O. Innate immunity of the newborn: basic mechanisms and clinical correlates. Nat Rev Immunol (2007) 7:379-90. doi:10.1038/nri2075

138. Itoh M, Takahashi T, Sakaguchi N, Kuniyasu Y, Shimizu J, Otsuka F, et al. Thymus and autoimmunity: production of $\mathrm{CD} 25+\mathrm{CD} 4+$ naturally anergic and suppressive $\mathrm{T}$ cells as a key function of the thymus in maintaining immunologic self-tolerance. J Immunol (1999) 162:5317-26.

139. Fontenot JD, Gavin MA, Rudensky AY. Foxp3 programs the development and function of CD4+CD25+ regulatory T cells. Nat Immunol (2003) 4:330-6. doi:10.1038/ni904

140. Hori S, Nomura T, Sakaguchi S. Control of regulatory T cell development by the transcription factor Foxp3. Science (2003) 299:1057-61. doi:10.1126/ science. 1079490

141. Khattri R, Cox T, Yasayko SA, Ramsdell F. An essential role for Scurfin in CD4+CD25+ T regulatory cells. Nat Immunol (2003) 4:337-42. doi:10.1038/ ni909

142. Passerini L, Bacchetta R. Forkhead-box-P3 gene transfer in human CD4+ T conventional cells for the generation of stable and efficient regulatory $\mathrm{T}$ cells, suitable for immune modulatory therapy. Front Immunol (2017) 8:1282. doi:10.3389/fimmu.2017.01282

143. Gao Q, Rouse TM, Kazmerzak K, Field EH. CD4+CD25+ cells regulate CD8 cell anergy in neonatal tolerant mice. Transplantation (1999) 68:1891-7. doi:10.1097/00007890-199912270-00013

144. Cosmi L, Liotta F, Lazzeri E, Francalanci M, Angeli R, Mazzinghi B, et al. Human CD8+CD25+ thymocytes share phenotypic and functional features with CD4+CD25+ regulatory thymocytes. Blood (2003) 102:4107-14. doi:10.1182/blood-2003-04-1320

145. Li S, Xie Q, Zeng Y, Zou C, Liu X, Wu S, et al. A naturally occurring CD8(+) CD122(+) T-cell subset as a memory-like Treg family. Cell Mol Immunol (2014) 11:326-31. doi:10.1038/cmi.2014.25

146. Vuddamalay Y, Van Meerwijk JP. CD28- and CD28lowCD8+ regulatory T cells: of mice and men. Front Immunol (2017) 8:31. doi:10.3389/fimmu. 2017.00031

147. Adams B, Nagy N, Paulart F, Vanderhaeghen ML, Goldman M, Flamand V. $\mathrm{CD} 8+\mathrm{T}$ lymphocytes regulating Th2 pathology escape neonatal tolerization. J Immunol (2003) 171:5071-6. doi:10.4049/jimmunol.171.10.5071 
148. Field AC, Caccavelli L, Bloch MF, Bellon B. Regulatory CD8+ T cells control neonatal tolerance to a Th2-mediated autoimmunity. J Immunol (2003) 170:2508-15. doi:10.4049/jimmunol.170.5.2508

149. Arenas-Hernandez M, Romero R, St Louis D, Hassan SS, Kaye EB, Gomez-Lopez N. An imbalance between innate and adaptive immune cells at the maternal-fetal interface occurs prior to endotoxin-induced preterm birth. Cell Mol Immunol (2016) 13:462-73. doi:10.1038/cmi. 2015.22

150. Williams J, Pomeroy NE, Pop-Busui R, Lash R, Douyon L, Chames M, et al. Case report: exenatide use during pregnancy. Endocrinologist (2009) 19:119-21. doi:10.1097/TEN.0b013e3181a5875e
Conflict of Interest Statement: The authors declare that the research was conducted in the absence of any commercial or financial relationships that could be construed as a potential conflict of interest.

Copyright $\odot 2018$ Garcia-Flores, Romero, Miller, Xu, Done, Veerapaneni, Leng, ArenasHernandez, Khan, Panaitescu, Hassan, Alvarez-Salas and Gomez-Lopez. This is an open-access article distributed under the terms of the Creative Commons Attribution License (CC BY). The use, distribution or reproduction in other forums is permitted, provided the original author(s) and the copyright owner are credited and that the original publication in this journal is cited, in accordance with accepted academic practice. No use, distribution or reproduction is permitted which does not comply with these terms. 